\title{
Weak precipitation, warm winters and springs impact glaciers of south slopes of Mt. Everest (central Himalaya) in the last 2 decades (1994-2013)
}

\author{
F. Salerno ${ }^{1,4}$, N. Guyennon ${ }^{2}$, S. Thakuri ${ }^{1,4}$, G. Viviano ${ }^{1}$, E. Romano ${ }^{2}$, E. Vuillermoz ${ }^{4}$, P. Cristofanelli ${ }^{3,4}$, P. Stocchi $^{3}$, \\ G. Agrillo ${ }^{3}$, Y. Ma ${ }^{5}$, and G. Tartari ${ }^{1,4}$ \\ ${ }^{1}$ National Research Council, Water Research Institute, Brugherio (IRSA-CNR), Italy \\ ${ }^{2}$ National Research Council, Water Research Institute, Roma (IRSA-CNR), Italy \\ ${ }^{3}$ National Research Council, Institute of Atmospheric Sciences and Climate (ISAC-CNR) Bologna, Italy \\ ${ }^{4}$ Ev-K2-CNR Committee, Via San Bernardino, 145, Bergamo 24126, Italy \\ ${ }^{5}$ Institute of Tibetan Plateau Research, Chinese Academy of Science, Beijing, China
}

Correspondence to: F. Salerno (salerno@irsa.cnr.it)

Received: 22 September 2014 - Published in The Cryosphere Discuss.: 1 December 2014

Revised: 5 May 2015 - Accepted: 28 May 2015 - Published: 17 June 2015

\begin{abstract}
Studies on recent climate trends from the Himalayan range are limited, and even completely absent at high elevation ( $>5000 \mathrm{~m}$ a.s.1.). This study specifically explores the southern slopes of Mt. Everest, analyzing the time series of temperature and precipitation reconstructed from seven stations located between 2660 and $5600 \mathrm{~m}$ a.s.l. during 1994-2013, complemented with the data from all existing ground weather stations located on both sides of the mountain range (Koshi Basin) over the same period. Overall we find that the main and most significant increase in temperature is concentrated outside of the monsoon period. Above $5000 \mathrm{~m}$ a.s.l. the increasing trend in the time series of minimum temperature $\left(+0.072{ }^{\circ} \mathrm{C} \mathrm{yr}^{-1}\right)$ is much stronger than of maximum temperature $\left(+0.009^{\circ} \mathrm{C} \mathrm{yr}^{-1}\right)$, while the mean temperature increased by $+0.044^{\circ} \mathrm{C} \mathrm{yr}^{-1}$. Moreover, we note a substantial liquid precipitation weakening $\left(-9.3 \mathrm{~mm} \mathrm{yr}^{-1}\right)$ during the monsoon season. The annual rate of decrease in precipitation at higher elevations is similar to the one at lower elevations on the southern side of the Koshi Basin, but the drier conditions of this remote environment make the fractional loss much more consistent ( $-47 \%$ during the monsoon period). Our results challenge the assumptions on whether temperature or precipitation is the main driver of recent glacier mass changes in the region. The main implications are the following: (1) the nega-
\end{abstract}

tive mass balances of glaciers observed in this region can be more ascribed to a decrease in accumulation (snowfall) than to an increase in surface melting; (2) the melting has only been favoured during winter and spring months and close to the glaciers terminus; (3) a decrease in the probability of snowfall $(-10 \%)$ has made a significant impact only at glacier ablation zone, but the magnitude of this decrease is distinctly lower than the observed decrease in precipitation; (4) the decrease in accumulation could have caused the observed decrease in glacier flow velocity and the current stagnation of glacier termini, which in turn could have produced more melting under the debris glacier cover, leading to the formation of numerous supraglacial and proglacial lakes that have characterized the region in the last decades.

\section{Introduction}

The current uncertainties concerning the glacial shrinkage in the Himalayas are mainly attributed to a lack of measurements, both of the glaciers and of climatic forcing agents (e.g., Bolch et al., 2012). Recent results underline the need for a fine-scale investigation, especially at high altitude, to better model the hydrological dynamics in this area. However, there are few high elevation weather stations in the 
world where the glaciers are located (Tartari et al., 2009). This can be attributed to the remote location of glaciers, the rugged terrain, and a complex political situation, all of which make physical access difficult (Bolch et al., 2012). As a consequence of the remoteness and difficulty in accessing many high elevation sites combined with the complications of operating automated weather stations (AWSs) at these altitudes, long-term measurements are challenging (Vuille, 2011). However, nearly all global climate models report increased sensitivity to warming at high elevations (e.g., Rangwala and Miller, 2012), while observations are less clear (Pepin and Lundqist, 2008). Moreover, changes in the timing or amount of precipitation are much more ambiguous and difficult to detect, and there is no clear evidence of significant changes in total precipitation patterns in most mountain regions (Vuille, 2011).

The need for a fine-scale investigation is particularly evident on the south slope of Mt. Everest (central southern Himalaya, $\mathrm{CH}-\mathrm{S}$ ) as it is one of the heavily glaciated parts of the Himalaya (Salerno et al., 2012; Thakuri et al., 2014). Nevertheless, these glaciers have the potential to build up morainedammed lakes storing large quantities of water, which are susceptible to GLOFs (glacial lake outburst floods) (e.g., Salerno et al., 2012; Fujita et al., 2013). Gardelle et al. (2011) noted that this region is most characterized by glacial lakes in the Hindu Kush Karakorum Himalaya. Recently, Thakuri et al. (2014) noted that the Mt. Everest glaciers experienced an accelerated shrinkage in the last 20 years (1992-2011), as underlined by an upward shift of the snow line altitude (SLA) with a velocity almost 3 times greater than the previous period (1962-1992). Furthermore Bolch et al. (2011) and Nuimura et al. (2012) found a higher mass loss rate during the last decade (2000-2010). However, to date, there are no continuous meteorological time series able to clarify the causes of the melting process to which the glaciers of these slopes are subjected.

In this context, since the early 1990s, PYRAMID Observatory Laboratory ( $5050 \mathrm{~m}$ a.s.l.) was created by the $E v-K 2$ CNR Committee (www.evk2cnr.org). This observatory is located at the highest elevation at which weather data have ever been collected in the region and thus represents a valuable data set with which to investigate the climate change in $\mathrm{CH}-\mathrm{S}$ (Tartari et al., 2002; Lami et al., 2010). However, the remoteness and the harsh conditions of the region over the years have complicated the operations of the AWSs, obstructing long-term measurements from a unique station.

In this paper, we mainly explore the small-scale climate variability of the south slopes of Mt. Everest by analyzing the minimum, maximum, and mean air temperature $(T)$ and liquid precipitation (Prec) time series reconstructed from seven AWSs located from 2660 to $5600 \mathrm{~m}$ a.s.l. over the last couple of decades (1994-2013). Moreover, we complete this analysis with all existing weather stations located on both sides of the Himalayan range (Koshi Basin) for the same period. In general, this study has the ultimate goal of linking the climate change patterns observed at high elevation with the glacier responses over the last 20 years, during which a more rapid glacier shrinkage process occurred in the region of investigation.

\section{Region of investigation}

The current study is focused on the Koshi (KO) Basin which is located in the eastern part of central Himalaya $(\mathrm{CH})$ (Yao et al., 2012; Thakuri et al., 2014). To explore possible differences in the surroundings of Mt. Everest, we decided to consider the north and south parts of $\mathrm{CH}$ (with the suffixes -N and -S, respectively) separately (Fig. 1a). The KO River $\left(58100 \mathrm{~km}^{2}\right.$ of the basin) originates in the Tibetan Plateau (TP) and the Nepali highlands. The area considered in this study is within the latitudes of 27 and $28.5^{\circ} \mathrm{N}$ and longitudes of 85.5 and $88^{\circ} \mathrm{E}$. The altitudinal gradient of this basin is the highest in the world, ranging from 77 to $8848 \mathrm{~m}$ a.s.l., i.e. Mt. Everest. We subdivide the KO Basin into the northern side (KO-N), belonging to the $\mathrm{CH}-\mathrm{N}$, and southern side (KO$\mathrm{S})$, belonging to the CH-S. The southern slopes of Mt. Everest are part of the Sagarmatha (Everest) National Park (SNP) (Fig. 1b), where the small-scale climate variability at high elevation is investigated. The SNP is the world's highest protected area, with over 30000 tourists in 2008 (Salerno et al., 2010a, 2013). The park area $\left(1148 \mathrm{~km}^{2}\right)$, extending from an elevation of 2845-8848 m a.s.l., covers the upper Dudh Koshi (DK) Basin (Manfredi et al., 2010; Amatya et al., 2010). Land-cover classification shows that almost one-third of the territory is characterized by glaciers and ice cover (Salerno et al., 2008; Tartari et al., 2008), while less than $10 \%$ of the park area is forested (Bajracharya et al., 2010; Salerno et al., 2010b). The SNP presents a broad range of bioclimatic conditions with three main bioclimatic zones: the zone of alpine scrub; the upper alpine zone, which includes the upper limit of vegetation growth; and the Arctic zone, where no plants can grow (UNEP and WCMC, 2008). Figure 1c shows the glacier distribution along the hypsometric curve of the SNP. We observe that the glacier surfaces are distributed from $4300 \mathrm{~m}$ to above $8000 \mathrm{~m}$ a.s.l., with more than $75 \%$ of the glacier surfaces lying between $5000 \mathrm{~m}$ and $6500 \mathrm{~m}$ a.s.l. The 2011 area-weighted mean elevation of the glaciers was $5720 \mathrm{~m}$ a.s.l. (Thakuri et al., 2014). These glaciers are identified as the summer accumulation-type fed mainly by summer Prec from the South Asian monsoon system, whereas the winter Prec caused by the mid-latitude westerly wind is minimal (Yao et al., 2012). The prevailing direction of the monsoons is S-N and SW-NE (e.g., Ichiyanagi et al., 2007). The climate is influenced by the monsoon system because the area is located in the subtropical zone with nearly $90 \%$ of the annual Prec falling in the months of June-September (this study). Heavy autumn and winter snowfalls can occur in association with tropical cyclones and westerly disturbances, respectively, and snow accumulation can occur at 

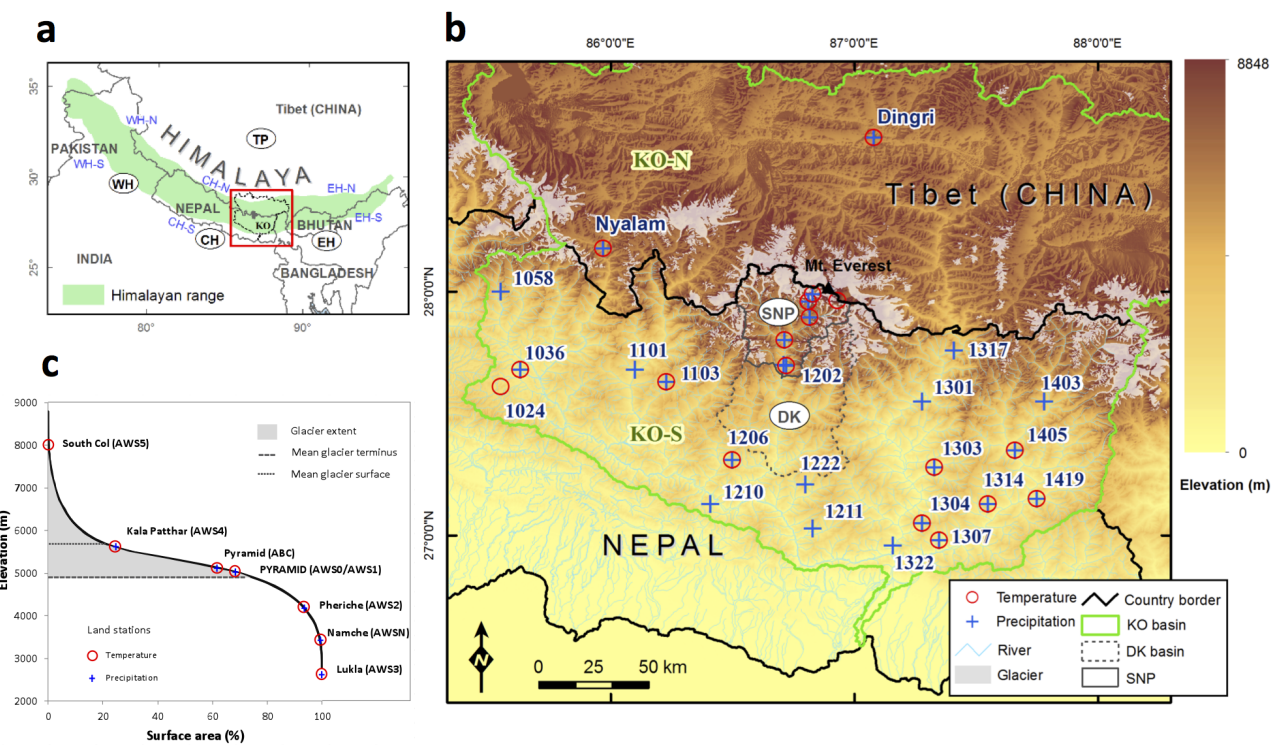

Figure 1. (a) Location of the study area in the Himalaya, where the abbreviations $\mathrm{WH}, \mathrm{CH}$, EH represents the western, central and eastern Himalaya, respectively (the suffixes $-\mathrm{N}$ and $-\mathrm{S}$ indicate the northern and southern slopes). (b) Focused map on the spatial distribution of all meteorological stations used in this study, where KO and DK stand for the Koshi and Dudh Koshi Basins, respectively; SNP represents the Sagarmatha National Park. (c) Hypsometric curve of SNP (upper DK Basin) and altitudinal glacier distribution. Along this curve, the locations of meteorological stations belonging to PYRAMID Observatory Laboratory are presented.

high elevations at all times of the year (Benn et al., 2012). Bollasina et al. (2011) have demonstrated the presence of well-defined local circulatory systems in the Khumbu Valley (SNP). The local circulation is dominated by a system of mountain and valley breezes. The valley breeze blows (approximately $4 \mathrm{~m} \mathrm{~s}^{-1}$ ) from the south every day from sunrise to sunset throughout the monsoon season, pushing the clouds that bring Prec northward.

\section{Data}

\subsection{Weather stations at high elevation}

The first automatic weather station (named hereafter AWS0) at $5050 \mathrm{~m}$ a.s.l. near PYRAMID Observatory Laboratory (Fig. 1c), was established in October 1993, it has run continuously all year round (Bertolani et al., 2000). The station, operating in extreme conditions, had recorded longterm ground-based temperature and temperature data which are considered valid until December 2005. Due to the obsolescence of technology, the station was disposed of in 2006. A new station (named hereafter AWS1) was installed just a few tens of meters away from AWS0 and has been operating since October 2000. Other stations were installed in the following years in the upper DK Basin in the Khumbu Valley (Table 1). In 2008, the network included sixth monitoring points, including the highest weather station of the world, located at South Col of Mt. Everest (7986 m a.s.1.). The locations of all stations are presented in Fig. 1b. We can ob- serve in Fig. 1c that this meteorological network well represents the climatic conditions of the SNP glaciers: AWS0 and AWS1 (5035 ma.s.1.) characterize the glacier fronts (4870 m a.s.1.), AWS4 (5600 $\mathrm{m}$ a.s.1.) represents the mean elevation of glaciers in the area (5720 m a.s.1.), and AWS5, the surface station at South Col (7986 m a.s.1.), characterizes the highest peaks ( $8848 \mathrm{~m}$ a.s.1.).

All stations, except AWS5 (only T), record at least $T$ and Prec. This data set presents some gaps (listed in Table 1) as a consequence of the complications of operating AWS at these altitudes. The list of measured variables for each station and relevant data can be downloaded from http://geonetwork.evk2cnr.org/. Data processing and quality checks are performed according to the international standards of the WMO (World Meteorological Organization).

The Prec sensors at these locations are conventional heated tipping buckets which may not fully capture the solid Prec. Therefore, solid Prec is probably underestimated, especially in winter. However, in order to know the magnitude of the possible underestimation of the solid phase, we compared the monthly mean Prec of the reconstructed PYRAMID series (1994-2013 period) with the Prec of a station located downstream at $2619 \mathrm{~m}$ a.s.l. (Chaurikhark, ID 1202), (Fig. 1b, Table 2) which presents monthly mean temperature above $0{ }^{\circ} \mathrm{C}$ even during the winter and thus a high prevalence of liquid Prec also during these months. This comparison, supported by the elevated correlation existing between the monthly Prec of the two stations, shows a slight underestimation of the PYRAMID snow (about $3 \pm 1 \%$ of total annual precipitation 
Table 1. List of surface stations belonging to PYRAMID Observatory Laboratory network located along the south slopes of Mt. Everest (upper DK Basin).

\begin{tabular}{|c|c|c|c|c|c|c|c|c|c|}
\hline \multirow{2}{*}{$\begin{array}{l}\text { Station } \\
\text { ID }\end{array}$} & \multirow[t]{2}{*}{ Location } & \multirow{2}{*}{$\begin{array}{r}\text { Latitude } \\
{ }^{\circ} \mathrm{N}\end{array}$} & \multirow{2}{*}{$\begin{array}{r}\text { Longitude } \\
{ }^{\circ} \mathrm{E}\end{array}$} & \multirow{2}{*}{$\begin{array}{c}\text { Elevation } \\
\text { ma.s.l. }\end{array}$} & \multirow{2}{*}{$\begin{array}{l}\text { Sampling } \\
\text { Frequency }\end{array}$} & \multicolumn{2}{|c|}{ Data Availability } & \multicolumn{2}{|c|}{$\%$ of daily missing data } \\
\hline & & & & & & From & To & Air Temperature & Precipitation \\
\hline AWS3 & Lukla & 27.70 & 86.72 & 2660 & $1 \mathrm{~h}$ & 2 Nov 2004 & 31 Dec 2012 & 23 & 20 \\
\hline AWSN & Namche & 27.80 & 86.71 & 3570 & $1 \mathrm{~h}$ & 27 Oct 2001 & 31 Dec 2012 & 21 & 27 \\
\hline AWS2 & Pheriche & 27.90 & 86.82 & 4260 & $1 \mathrm{~h}$ & 25 Oct 2001 & 31 Dec 2013 & 15 & 22 \\
\hline AWS0 & Pyramid & 27.96 & 86.81 & 5035 & $2 \mathrm{~h}$ & 1 Jan 1994 & 31 Dec 2005 & 19 & 16 \\
\hline AWS1 & Pyramid & 27.96 & 86.81 & 5035 & $1 \mathrm{~h}$ & 1 Jan 2000 & 31 Dec 2013 & 10 & 21 \\
\hline $\mathrm{ABC}$ & Pyramid & 27.96 & 86.82 & 5079 & $1 \mathrm{~h}$ & 1 Mar 2006 & 31 Dec 2011 & 5 & 1 \\
\hline AWS4 & Kala Patthar & 27.99 & 86.83 & 5600 & $10 \mathrm{~min}$ & 1 Jan 2009 & 31 Dec 2013 & 28 & 38 \\
\hline AWS5 & South Col & 27.96 & 86.93 & 7986 & $10 \mathrm{~min}$ & 1 May 2008 & 31 Dec 2011 & 39 & 100 \\
\hline
\end{tabular}

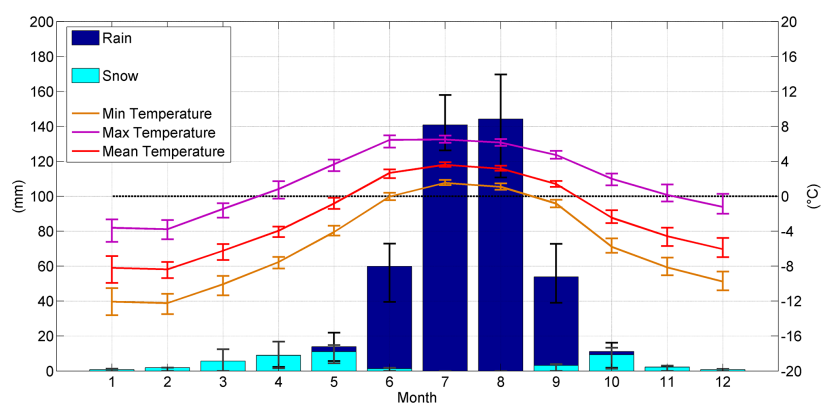

Figure 2. Mean monthly cumulated precipitation subdivided into snowfall and rainfall and minimum, maximum, and mean temperature at $5050 \mathrm{~m}$ a.s.1. (reference period 1994-2013). The bars represent the standard deviation.

registered at PYRAMID, see Supplement Sect. 3 for more details). Therefore, having much reduced the underestimation, we decided not to manipulate data. However the trends hereafter reported refer mainly to the liquid phase of Prec. In this regard, according to both Fujita and Sakai (2014) and field observations (Ueno et al., 1994), the precipitation phase has been taken into account assuming that the probability of snowfall and rainfall depends on mean daily air temperature, using as thresholds - as proposed by the aforementioned authors -0 and $4{ }^{\circ} \mathrm{C}$, respectively. In Fig. 2 we first of all observe that at $5050 \mathrm{~m}$ a.s.l. $90 \%$ of precipitation is concentrated during June-September and that the probability of snowfall is very low (4\%), considering that the mean daily temperature during these months is above $0{ }^{\circ} \mathrm{C}$. On a yearly basis, this probability reaches $20 \%$ of the annual cumulated precipitation.

\subsection{Other weather stations at lower altitude in the Koshi Basin}

In KO-S Basin (Nepal), the stations are operated by the Department of Hydrology and Meteorology (DHM) (www.dhm. gov.np/). For daily $T$ and Prec, we selected 10 stations for $T$ and 19 stations for Prec considering both the length of the se- ries and the monitoring continuity $(<10 \%$ of missing daily data). The selected stations cover an elevation range between 158 and $2619 \mathrm{~m}$ a.s.l. (Table 3). In KO-N Basin (TP, China), the number of ground weather stations (operated by the Chinese Academy of Science (CAS)), selected with the same criteria mentioned above, is considerably smaller, just two, but these stations have a higher elevation ( $4302 \mathrm{~m}$ a.s.l. for the Dingri station and $3811 \mathrm{~m}$ a.s.l. for the Nyalam station).

The quality insurance of these meteorological data is ensured considering that they are used as part of global and regional networks including for instance APHRODITE (Asian Precipitation-Highly Resolved Observational Data Integration Towards Evaluation of Water Resources) (Yasutomi et al., 2011) and GHCN (Global Historical Climatology Network) (Menne et al., 2012).

\section{Methods}

We define the pre-monsoon, monsoon, and post-monsoon seasons as the months from February to May, June to September, and October to January, respectively. The minT, maxT, and meanT are calculated as the minimum, maximum, and mean daily air temperature. For total precipitation (Prec), we calculate the mean of the cumulative precipitation for the analyzed period.

\subsection{Reconstruction of the daily temperature and precipitation time series at high elevation}

The two stations named AWS0 and AWS1 in the last 20 years, considering the extreme weather conditions of this area, present a percentage of missing daily values of approximately $20 \%$ (Table 1). The other stations (hereafter named secondary stations) were used here for infilling the gaps according to a priority criteria based on the degree of correlation among data. AWS1 was chosen as the reference station given the length of the time series and that it is currently still operating. Therefore, our reconstruction (hereafter named PYRAMID) is referred to an elevation of $5035 \mathrm{~m}$ a.s.l. 


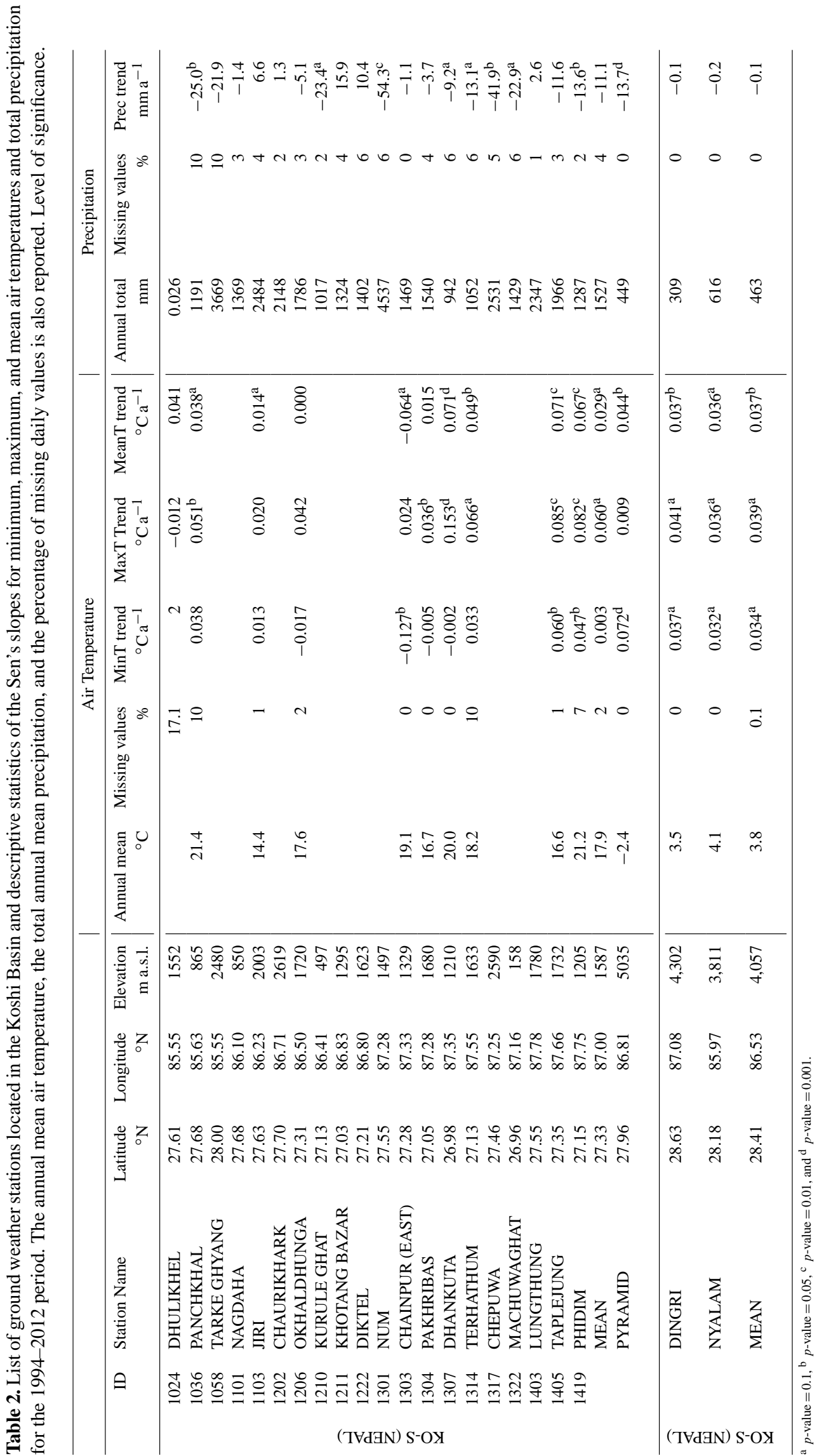




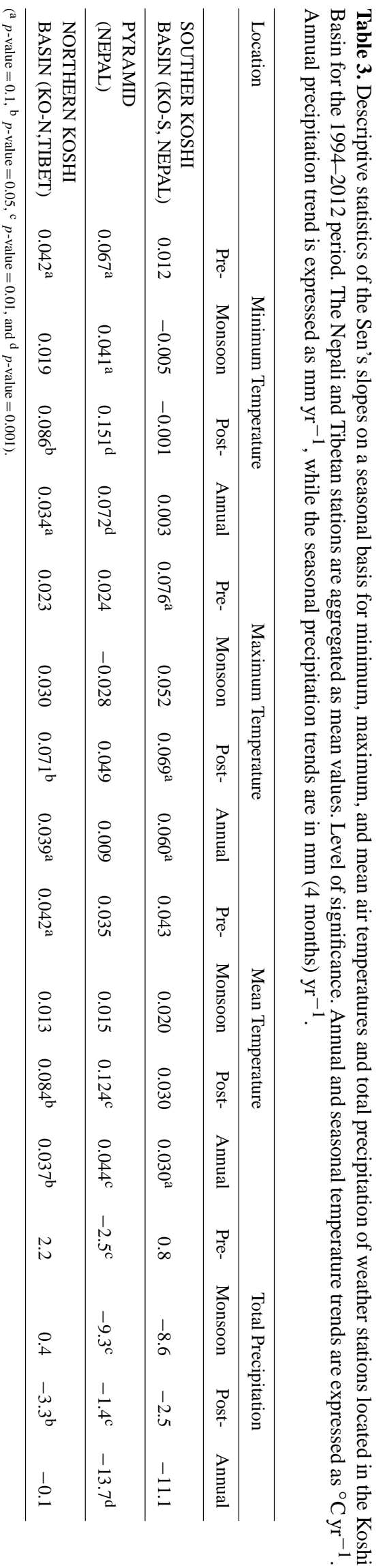

The selected infilling method is a simple regression analysis based on quantile mapping (e.g., Déqué, 2007; Themeß1 et al., 2012). This regression method has been preferred to more complex techniques, such as the fuzzy rule-based approach (Abebe et al., 2000) or the artificial neural networks (Abudu et al., 2010; Coulibaly and Evora, 2007), considering the peculiarity of this case study. In fact, all stations are located in the same valley (Khumbu Valley). This aspect confines the variance among the stations to the altitudinal gradient of the considered variable ( $T$ or Prec), which can be easily reproduced by the stochastic link created by the quantile mapping method. In case all stations registered a simultaneous gap, we apply a multiple imputation technique (Schneider, 2001) that uses some other proxy variables to fill the remaining missing data. Details on the reconstruction procedure and the computation of the associated uncertainty are provided in Supplement Sect. 1.

\subsection{The trends analysis: the sequential Mann-Kendall test}

The Mann-Kendall (MK) test (Kendall, 1975) is widely adopted to assess significant trends in hydro-meteorological time series (e.g., Carraro et al., 2012a, b; Guyennon et al., 2013). This test is non-parametric, thereby less sensitive to extreme sample values, and is independent of the hypothesis about the nature of the trend, whether linear or not. The MK test verifies the assumption of the stationarity of the investigated series by ensuring that the associated normalized Kendall's tau coefficient, $\mu(\tau)$, is included within the confidence interval for a given significance level (for $\alpha=5 \%$, the $\mu(\tau)$ is below -1.96 and above 1.96). In the sequential form (seqMK) (Gerstengarbe and Werner, 1999), $\mu(\tau)$ is calculated for each element of the sample. The procedure is applied forward starting from the oldest values (progressive) and backward starting from the most recent values (retrograde). If no trend is present, the patterns of progressive and retrograde $\mu(\tau)$ vs. time (i.e. years) present several crossing points, while a unique crossing period allows the approximate location of the starting point of the trend (e.g., Bocchiola and Diolaiuti, 2010).

In this study, the seqMK is applied to monthly vectors. Monitoring the seasonal non-stationarity, the monthly progressive $\mu(\tau)$ is reported with a pseudo colour code, where the warm colours represent the positive slopes and cold colours the negative ones. Colour codes associated with values outside of the range ( -1.96 to 1.96$)$ possess darker tones to highlight the trend significance (Salerno et al., 2014). Moreover, to monitor the overall non-stationarity of the time series, both the progressive and the retrograde $\mu(\tau)$ at the annual scale are reported. We used the Sen's slope proposed by Sen (1968) as a robust linear regression allowing the quantification of the potential trends revealed by the seqMK (e.g., Bocchiola and Diolaiuti, 2010). The significance level is established for $p<0.05$. We define a slight significance for 

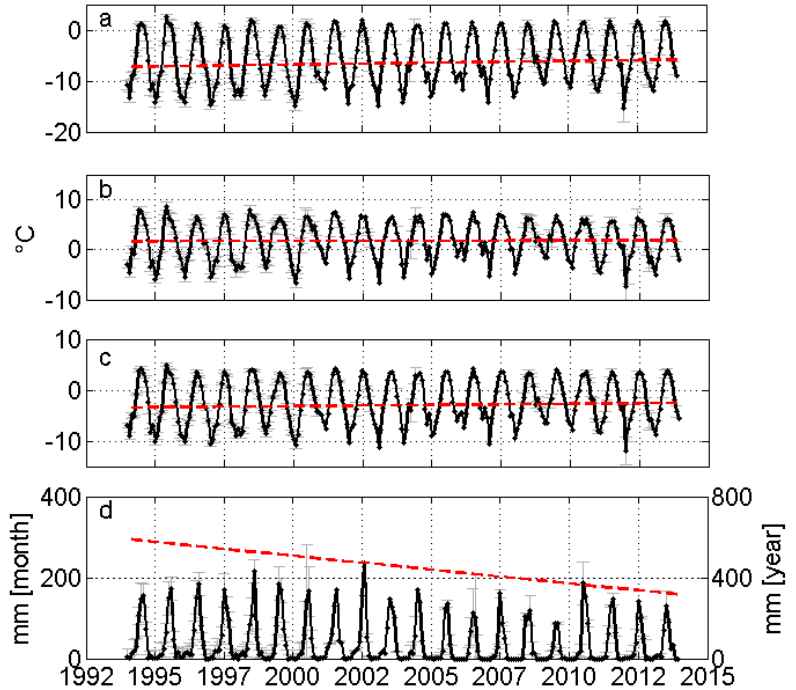

Figure 3. Temperature and precipitation monthly time series (19942013) reconstructed at high elevations of Mt. Everest (PYRAMID): minimum (a), maximum (b), and mean temperature (c), and precipitation (d). Uncertainty at $95 \%$ is presented as a grey bar. The red lines represents the robust linear fitting of the time series characterized by the associated Sen's slope. According to Dytham (2011), the intercepts are calculated by taking the slopes back from every observation to the origin. The intercepts used in here represent the median values of the intercepts calculated for every point (Lavagnini et al., 2011). For precipitation the linear fitting refers to the right axis.

$p<0.10$. The uncertainty associated with the Sen's slopes (1994-2013) is estimated through a Monte Carlo uncertainty analysis (e.g., James and Oldenburg, 1997), described in detail in Supplement Sect. 1.

\section{Results}

\subsection{Trend analysis at high elevation}

Figure 3 shows the reconstructed PYRAMID time series for $\operatorname{minT}$, maxT, meanT, and Prec resulting from the overall infilling process explained in Supplement Sect. 1. Figure 4 analyzes the monthly trends of $T$ and Prec from 1994 to 2013 for PYRAMID.

\section{Minimum air temperature $(\min T)$}

November $\left(+0.17^{\circ} \mathrm{Cyr}^{-1}, \quad p<0.01\right)$ and December $\left(+0.21^{\circ} \mathrm{C} \mathrm{yr}^{-1}, p<0.01\right)$ present the highest increasing trend; i.e. both of these 2 months experienced about an even $+4{ }^{\circ} \mathrm{C}$ increase over 20 years (Fig. 4a). In general, the post- and pre-monsoon periods experience higher and more significant increases than during the monsoon. In particular, we note the significant and consistent increase of minT of April $\left(+0.10^{\circ} \mathrm{C} \mathrm{yr}^{-1}, p<0.05\right)$. At the annual scale, the bottom graph shows a progressive $\mu(\tau)$ trend parallel to the retrograde $\mu(\tau)$ one for the entire analyzed period, i.e. a continuous tendency of minT to rise, which becomes significant in 2007, when the progressive $\mu(\tau)$ assumes values above +1.96 . On the right, the Sen's slope completes the analysis, illustrating that minT is increasing at annual level by $+0.072 \pm 0.011^{\circ} \mathrm{C} \mathrm{yr}^{-1}, p<0.001$, i.e. $+1.44 \pm 0.22{ }^{\circ} \mathrm{C}$ over 20 years.

\section{Maximum air temperature $(\max T)$}

The post- and pre-monsoon months show larger increases in maxT, but with lower magnitudes and significance than we observe for minT (Fig. 4b). The highest increases for this variable occurs also for maxT in April, November and December. Less expected is the decrease of maxT in May $\left(-0.08^{\circ} \mathrm{C} \mathrm{yr}^{-1}, p<0.05\right)$ and during the monsoon months from June to August $\left(-0.05^{\circ} \mathrm{C} \mathrm{yr}^{-1}, p<0.1\right)$. On the annual scale, the bottom graph shows a continuous crossing of the progressive and retrograde $\mu(\tau)$ trends until 2007, i.e. a general stationary condition. From 2007 until 2010, the trend significantly increased, while 2012 and 2013 register a decrease, bringing the progressive $\mu(\tau)$ near the stationary condition. In fact, on the right, the Sen's slope confirms that maxT is at annual level stationary over the 20 years $\left(+0.009 \pm 0.012{ }^{\circ} \mathrm{Cyr}^{-1}, p>0.1\right)$.

\section{Mean air temperature (meanT)}

Figure 4c, as expected, presents intermediate conditions for meanT in respect to minT and maxT. All months, except May and the monsoon months from June and August, register a positive trend (more or less significant). December presents the highest, more significant increasing trend $\left(+0.17^{\circ} \mathrm{Cyr}^{-1}, p<0.01\right)$, while April shows the highest, more significant increase $(p<0.10)$ during the pre-monsoon period. On the annual scale, the bottom graph shows that the progressive $\mu(\tau)$ trend has always increased since 2000 and that it becomes significant beginning in 2008. On the right, the Sen's slope concludes this analysis, showing that meanT has been significantly increasing by $+0.044 \pm 0.008^{\circ} \mathrm{C} \mathrm{yr}^{-1}$, $p<0.05$, i.e. $+0.88 \pm 0.16^{\circ} \mathrm{C}$ over 20 years.

\section{Total precipitation (Prec)}

In the last years, all cells are blue; i.e. we observe for all months an overall and strongly significant decreasing trend of Prec (Fig. 4d). In general, the post- and pre-monsoon periods experience more significant decreases, although the monsoon months (June-September) register the main Prec losses (e.g. August registers a Prec loss of even $-4.6 \mathrm{~mm} \mathrm{yr}^{-1}$ ). On the annual scale, the bottom graph shows a continuous decreasing progressive $\mu(\tau)$ trend since 2000 that becomes significant beginning in 2005. On the right, the Sen's slope notes that the decreasing Prec trend is strongly high and significant at annual level $\left(-13.7 \pm 2.4 \mathrm{~mm} \mathrm{yr}^{-1}, p<0.001\right)$. 


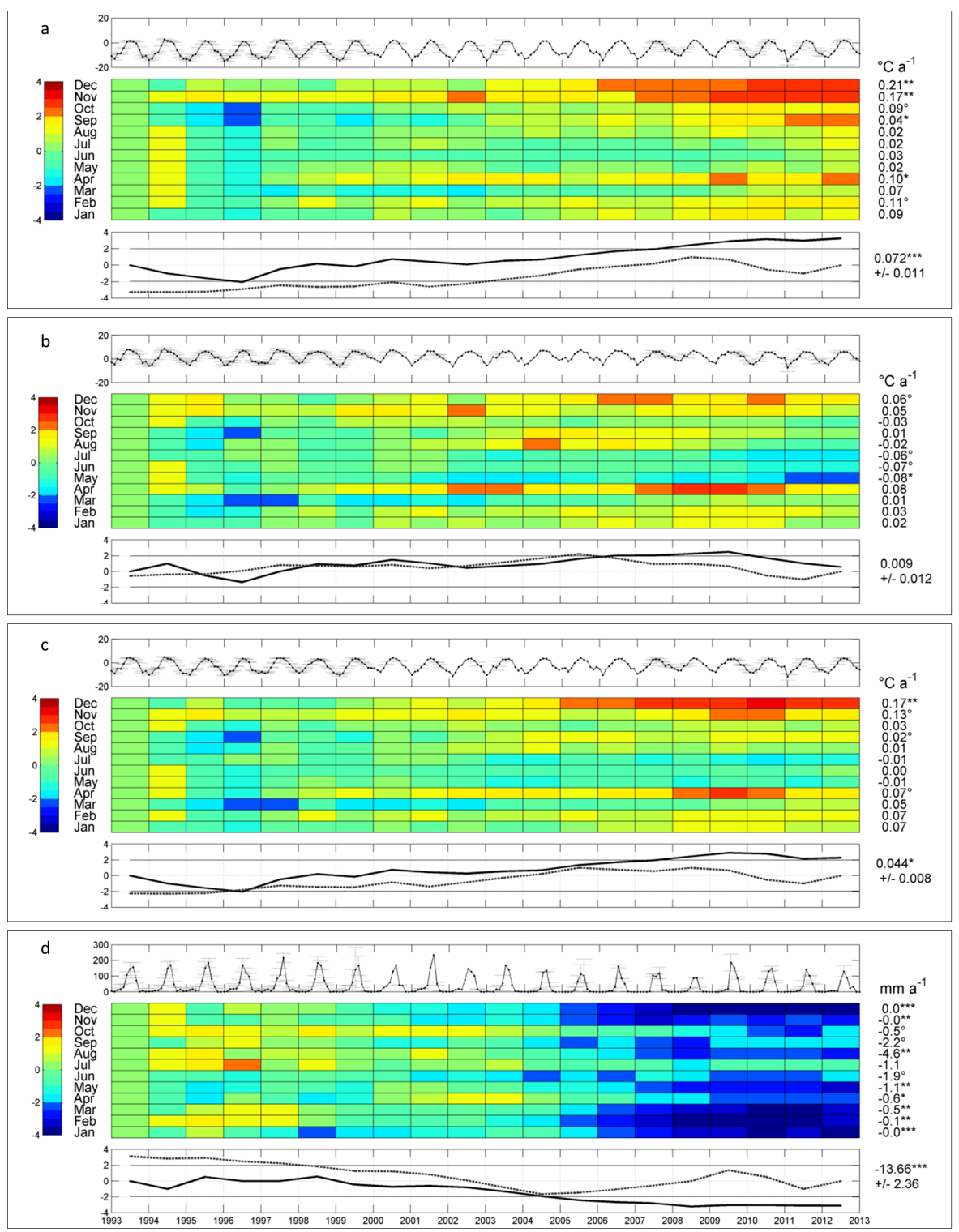

Figure 4. Trend analysis for (a) minimum, (b) maximum, and (c) mean air temperatures and (d) total precipitation in the upper DK Basin. The top graph of each meteorological variable shows the monthly trend (dark line) and uncertainty due to the reconstruction process (grey bars). The central grid displays the results of the sequential Mann-Kendall (seqMK) test applied at the monthly level. On the left, the colour bar represents the normalized Kendall's tau coefficient $\mu(\tau)$. The colour tones below -1.96 and above 1.96 are significant $(\alpha=5 \%)$. On the right, the monthly Sen's slopes and the relevant significance levels for the 1994-2013 period $\left(^{\circ} p\right.$-value $=0.1, * p$-value $=0.05$, $* *$ $p$-value $=0.01$, and $* * * p$-value $=0.001)$. The bottom graph plots the progressive (black line) and retrograde (dotted line) $\mu(\tau)$ applied on the annual scale. On the right, the annual Sen's slope is shown for the 1994-2013 period. MATLAB ${ }^{\circledR}$ script is available at http://www.irsa. cnr.it/Docs/Code/MSeqMK.m.

The precipitation reduction is mainly due to a reduction in intensity (cumulative precipitation for week). However, during the early and late monsoon, a reduction in duration (number of we days for week) is evident (see further details in Supplement Sect. 2).

\subsection{Trend analysis in the Koshi Basin}

Table 2 provides the descriptive statistics of the Sen's slopes for minT, maxT, meanT, and Prec for the 1994-2013 period for the Koshi Basin. The stations located on the two sides of the Himalayan range are listed separately. For the southern ones (KO-S), we observe that for minT less than half of the stations experience an increasing trend and just three are 
significant with $p<0.1$. In general, the minT on the southern side can be defined as stationary $\left(+0.003^{\circ} \mathrm{C} \mathrm{yr}^{-1}\right)$. Conversely, the maxT shows a decidedly non-stationary condition. All stations present an increasing trend, and even 6 of the 10 are rising significantly with at least $p<0.1$. The mean trend is $+0.060^{\circ} \mathrm{C} \mathrm{yr}^{-1}(p<0.10)$. Similarly, the meanT shows a substantial increase. Also in this case, 6 of the 10 stations are rising significantly with at least $p<0.1$. The mean trend is $+0.029^{\circ} \mathrm{C} \mathrm{yr}^{-1}(p<0.10)$. Regarding Prec, we observe that on the KO-S, 14 of the 19 stations present a downward trend. Among them, eight decrease significantly with at least $p<0.1$. The mean trend is $-11.1 \mathrm{~mm} \mathrm{yr}^{-1}$; i.e. we observe a decreasing of $15 \%(222 \mathrm{~mm})$ of precipitation fallen in the basin during the 1994-2013 period (1527 mm on average).

The two stations located on the northern ridge (KO$\mathrm{N})$ show a singularly slight significant rise for $\operatorname{minT}$ $\left(+0.034^{\circ} \mathrm{C} \mathrm{yr}^{-1}, \quad p<0.10\right.$ on average) and for $\operatorname{maxT}$ $\left(+0.039^{\circ} \mathrm{C} \mathrm{yr}^{-1}, p<0.10\right.$ on average), recording a consequent mean increase of meanT equal to $+0.037^{\circ} \mathrm{C} \mathrm{yr}^{-1}$, $p<0.05$. As for Prec, we observe that on the KO-N, both stations maintain stationary conditions $\left(-0.1 \mathrm{~mm} \mathrm{yr}^{-1}\right)$.

Table 3 provides the descriptive statistics of the Sen's slopes on a seasonal base. The stations analyzed here are the same as those considered in Table 2. We begin our description with PYRAMID, already analyzed in detail in Fig. 4. We confirm with this seasonal grouping that the main and significant increases of minT, maxT, and meanT are completely concentrated during the post-monsoon period (e.g., $+0.124^{\circ} \mathrm{C} \mathrm{yr}^{-1}, p<0.01$ for meanT). The premonsoon period experienced a slighter and not significant increase (e.g., $+0.035^{\circ} \mathrm{C} \mathrm{yr}^{-1}, p>0.1$ for meanT). In general, during the monsoon period, $\mathrm{T}$ is much more stationary for all three variables (e.g., $+0.015^{\circ} \mathrm{C} \mathrm{yr}^{-1}, p>0.1$ for meanT). Considering the other KO-S stations, the main increasing and significant trends of meanT occurred during the pre-monsoon $\left(+0.043^{\circ} \mathrm{C} \mathrm{yr}^{-1}\right)$ and post-monsoon $\left(+0.030^{\circ} \mathrm{C} \mathrm{yr}^{-1}\right)$ season, while the increase during the monsoon is slighter $\left(+0.020^{\circ} \mathrm{C} \mathrm{yr}^{-1}\right)$. The KO-N stations confirm that the main increasing trend of meanT occurred outside the monsoon period that is stationary $\left(+0.013^{\circ} \mathrm{C} \mathrm{yr}^{-1}\right)$.

As for Prec, PYRAMID and the other KO-S stations show that the magnitude of the Sen's slopes is higher during the monsoon season $\left(-9.3\right.$ and $-8.6 \mathrm{~mm} \mathrm{yr}^{-1}$, respectively), when precipitation is more abundant. The relatively low snowfall phase of monsoon Prec at PYRAMID (as specified above) makes the decreasing trend observed during the summer more robust than the annual one as devoid of the undervaluation of snowfall (albeit slight, as demonstrated above $(3 \pm 1 \%))$. The northern stations show slight significant decreasing Prec during the winter $\left(-3.3 \mathrm{~mm} \mathrm{yr}^{-1}, p<0.05\right)$.
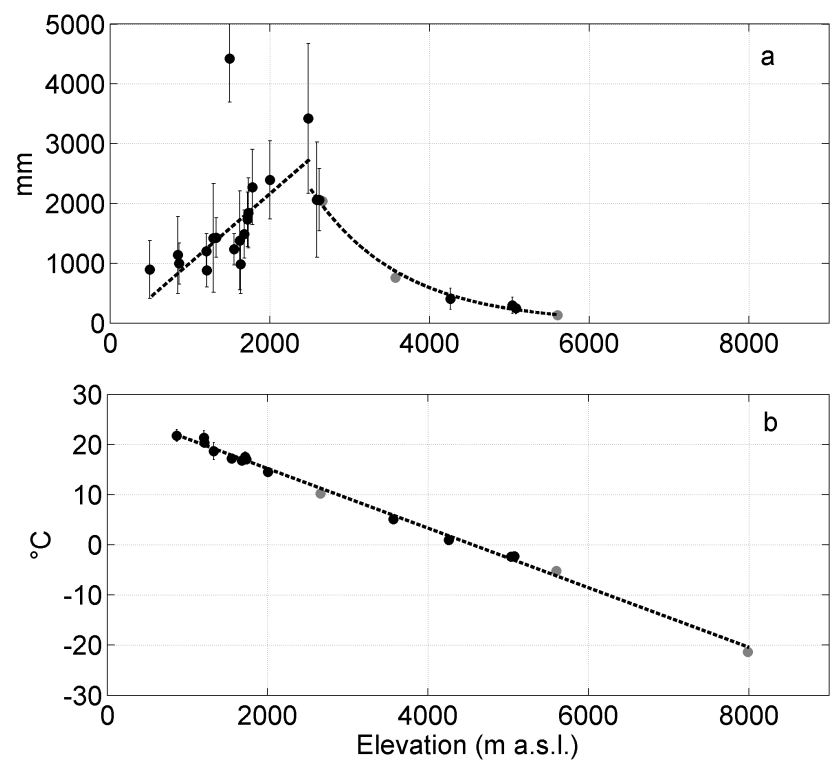

Figure 5. Lapse rates of (a) total annual precipitation in the Koshi Basin for the last 10 years (2003-2012) and (b) mean annual air temperature. The daily missing data threshold is set to $10 \%$. Only stations presenting at least 5 years of data (black points) are considered to create the regressions (the bars represent 2 standard deviations). Grey points indicate the stations presenting less than 5 years of data.

\subsection{Lapse rates in the southern Koshi Basin}

\subsubsection{Air temperature gradient}

This study, aiming to create a connection between the climate drivers and cryosphere in the Koshi Basin, which presents the highest altitudinal gradient of the world (77-8848 $\mathrm{m}$ a.s.1.), offers a unique opportunity to calculate $T$ and Prec lapse rates before analyzing their spatial trends. It is worth noting that the $T$ lapse rate is one of the most important variables for modelling meltwater runoff from a glacierized basin using the $T$-index method (Hock, 2005; Immerzeel et al., 2014). It is also an important variable for determining the form of Prec and its distribution characteristics (e.g., Hock, 2005). Figure $5 \mathrm{~b}$ presents the lapse rate of the annual meanT in the KO Basin (Nepal) along the altitudinal range of well over $7000 \mathrm{~m}$ (865-7986 ma.s.1.). We found an altitudinal gradient of $-0.60^{\circ} \mathrm{C}(100 \mathrm{~m})^{-1}$ on the annual scale with a linear trend $\left(r^{2}=0.98, p<0.001\right)$. It is known that up to altitudes of approximately $8-17 \mathrm{~km}$ a.s.l. in the lower regions of the atmosphere, $T$ decreases with altitude at a fairly uniform rate (Washington and Parkinson, 2005). Considering that the lapse rate is mainly affected by the moisture content of the air (Washington and Parkinson, 2005), we calculated the seasonal gradients (not shown here). We found a dry lapse rate of $-0.65^{\circ} \mathrm{C}(100 \mathrm{~m})^{-1}\left(r^{2}=0.99, p<0.001\right)$ during the premonsoon season when AWS1 registers a mean relative humidity of $62 \%$. A saturated lapse rate during the monsoon 
season is $-0.57^{\circ} \mathrm{C}(100 \mathrm{~m})^{-1}\left(r^{2}=0.99, p<0.001\right)$ with a mean relative humidity of $96 \%$. During the post-monsoon period, we found a lapse rate equal to that registered during the monsoon: $-0.57(100 \mathrm{~m})^{-1}\left(r^{2}=0.98, p<0.001\right)$ even if the relative humidity is decidedly lower in these months (44\%). Kattel et al. (2013) explain this anomalous low postmonsoon lapse rate as the effect of strong radiative cooling in winter.

\subsubsection{Precipitation gradient}

The relationship of Prec with elevation helps in providing a realistic assessment of water resources and hydrological medelling of mountainous regions (Barros et al., 2004). In recent years, the spatial variability of Prec has received attention because the mass losses of the Himalayan glaciers can be explained with an increased variability in the monsoon system (e.g., Yao et al., 2012; Thakuri et al., 2014).

Figure 5a shows the altitudinal gradient for the total annual Prec in the Koshi Basin. We observe a clear rise in Prec with elevation until approximately $2500 \mathrm{~m}$ a.s.l., corresponding to the Tarke Ghyang station (code 1058), registering an annual mean of $3669 \mathrm{~mm}$ (mean for the 2004-2012 period). A linear approximation $(r=0.83, p<0.001)$ provides a rate of $+1.16 \mathrm{~mm} \mathrm{~m}^{-1}$. At higher elevations, we observe an exponential decrease $\left(a e^{b x}\right.$, with $a=21168 \mathrm{~mm} \mathrm{~m}^{-1}$ and $b=-9 \times 10^{-4} \mathrm{~m}^{-1}$, where $x$ is the elevation expressed as $\mathrm{m}$ a.s.l.) until observing a minimum of $132 \mathrm{~mm}$ (years 2009 and 2013) for the Kala Patthar station (AWS4) at $5600 \mathrm{~m}$ a.s.l., although, as specified above, at these altitudes the contribution of winter snowfall could be slightly underestimated. The changing point between the two gradients can be reasonably assumed at approximately $2500 \mathrm{~m}$ a.s.l., considering that the stations here present the highest interannual variability, belonging in this way, depending on the year, to the linear increase or to the exponential decrease. The clear outlier along the linear gradient is the Num station (1301) located at $1497 \mathrm{~m}$ a.s.l., which recorded $4608 \mathrm{~mm}$ of precipitation. This station has been excluded for the linear approximation because, as reported by Montgomery and Stolar (2006), the station is located in the Arun Valley, which acts as a conduit for northward transport of monsoonal precipitation. The result is that local precipitation within the gorge of the Arun River is several times greater than in surrounding areas.

Some previous studies of the Himalayas have considered orographic effects on Prec (Singh and Kumar, 1997; Ichiyanagi et al., 2007). Ichiyanagi et al. (2007), using all available Prec stations operated by DHM, of which $<5 \%$ of stations are located over $2500 \mathrm{~m}$ and just one station is over $4000 \mathrm{~m}$ a.s.l., observed that in the $\mathrm{CH}$ $\mathrm{S}$ region, the annual Prec increases with altitude below $2000 \mathrm{~m}$ a.s.l. and decreases for elevations ranging between 2000 and $3500 \mathrm{~m}$ a.s.l., but with no significant gradient. A broad picture of the relationship between Prec and topography in the Himalayas can be derived from the precipita- tion radar onboard the Tropical Rainfall Measuring Mission (TRMM). Some authors found an increasing trend with elevation characterized by two distinct maxima along two elevation bands (950 and $2100 \mathrm{~m}$ a.s.l.). The second maximum is much higher than the first, and it is located along the lesser Himalayas. Over these elevations, the annual distribution follows an approximate exponentially decreasing trend (Bookhagen and Burbank, 2006).

Physically, we can interpret the Prec gradient of Fig. 5a considering that when the humid air masses coming from the Bay of Bengal collide with the orographic barrier, heavy convections induce huge quantity of rain below $2500 \mathrm{~m}$ a.s.l. The topographic barrier of the Himalayan mountain range causes the mechanical lift of the humid air, the cooling of the air column, the condensation and the consequent rainfall. The further increase in relief induces a depletion of the moisture content resulting in a severe reduction of Prec at higher altitudes. Our study, based on ground stations, confirms the general Prec gradient detected with the TRMM microwave observations, even if we did not identify a marked double maximum Prec peak as observed generally for the whole central Himalaya by Bookhagen and Burbank (2006). In fact these author report for our specific case study (profiles 14 and 15 of their Fig. 1b), a single step increase in relief associated with a single Prec maximum.5.4 Spatial distribution of air temperature and precipitation trends in the Koshi Basin

Figure 6 presents the spatial distribution of the Sen's slopes in the Koshi Basin for minT (Fig. 6a), maxT (Fig. 6b), meanT (Fig. 6c), and Prec (Fig. 6d) during the 1994-2013 period. The relevant data are reported in Table 2. The Chainpur (east) station shows $T$ trends in contrast with the other stations (see also Table 2); therefore, we consider this station as a local anomaly and do not discuss it further in the following sections.

Regarding minT, we observe an overall stationary condition on KO-S, as noted above. The only two stations showing a significant increasing trend are both located in the east. The high elevation stations (PYRAMID and both those located on the north ridge) differ from the general pattern of the southern basin by showing a significant increasing trend. Even for maxT, we observe a higher increase in the southeastern basin. The central and western parts of the KO-S seem to be more stationary. PYRAMID follows this stationary pattern, while the northern stations (KO-N) show large and significant increases. As a consequence, meanT shows increasing trends for all the Koshi Basin, especially on the southeast and northern sides.

The decrease of precipitation in the southern Koshi Basin presents a quite homogeneous pattern from which the highly elevated PYRAMID is not excluded. The pattern is different on the north ridge, where it is stationary. 


\section{Discussion}

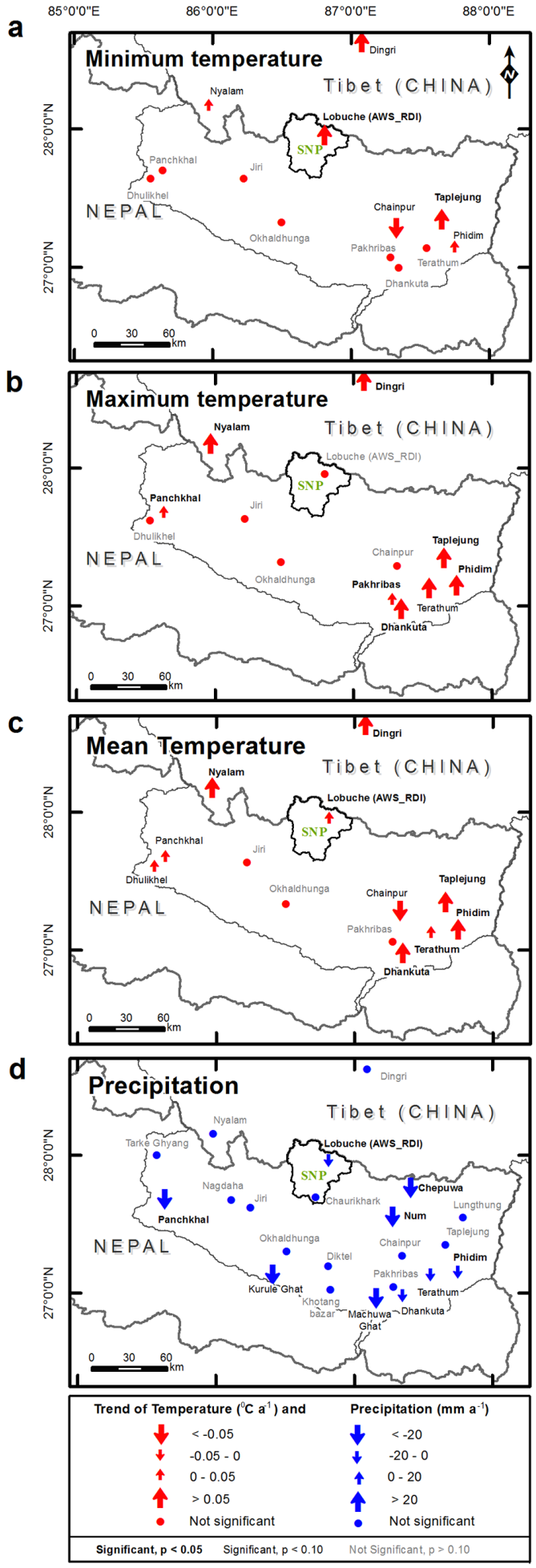

Figure 6. Spatial distribution of the Sen's slopes in the Koshi Basin for minimum (a), maximum (b), and mean (c) air temperature and (d) total precipitation for the 1994-2013 period. Data are reported in Table 2.

\subsection{Temperature trends of the Koshi Basin compared to the regional pattern}

The trend analysis carried out in this study for the last 2 decades on KO-S shows full consistency with the pattern of change (shown in the following) occurring in these regions over the last 3 decades in terms of a higher increase in $\operatorname{maxT}\left(+0.060^{\circ} \mathrm{C} \mathrm{yr}^{-1}\right)$ than in $\operatorname{minT}\left(+0.003{ }^{\circ} \mathrm{C} \mathrm{yr}^{-1}\right)$, a seasonal pattern (more pronounced during the pre- and postmonsoon months), and the magnitudes of the trends (e.g., the meanT trend is $+0.030^{\circ} \mathrm{C} \mathrm{yr}^{-1}$ ). Therefore, at low elevations of KO-S, we observe an acceleration of warming in the recent years compared to the rate of change reported by Kattel and Yao (2013) and Shrestha et al. (1999) in the previous decades.

At regional level, Kattel and Yao (2013) analyzed the annual minT, maxT, and meanT trends from stations ranging from $1304 \mathrm{~m}$ to $2566 \mathrm{~m}$ a.s.l. in $\mathrm{CH}-\mathrm{S}$ (corresponding to all stations in Nepal) during the 1980-2009 period. They found that the magnitude of warming is higher for maxT $\left(+0.065^{\circ} \mathrm{C} \mathrm{yr}^{-1}\right)$, while $\operatorname{minT}\left(+0.011^{\circ} \mathrm{Cyr}^{-1}\right)$ exhibits larger variability, such as positive, negative or no change; meanT was found to increase at an intermediate rate of $+0.038^{\circ} \mathrm{C} \mathrm{yr}^{-1}$. These authors extended some time series and confirmed the findings of Shrestha et al. (1999) that, analyzing the 1971-1994 period, found a maxT increase of $+0.059^{\circ} \mathrm{C} \mathrm{yr}^{-1}$ for all of Nepal. Furthermore, warming in the winter was more pronounced compared to other seasons in both studies. These results are consistent with the pattern reported in WH (e.g., Bhutiyani et al., 2007; Shekhar et al., 2010), in EH, and in the rest of India (e.g., Pal and Al-Tabbaa, 2010) for the last 3 decades.

The trend analysis carried out in this study for the last 2 decades on KO-N agrees with the regional studies (shown in the following) regarding both the considerable increase of $\operatorname{minT}\left(+0.034^{\circ} \mathrm{Cyr}^{-1}\right)$ and the seasonal consistency of trends, related to all three $T$ variables, outside the monsoon months. However, we observe that in recent years, maxT is increasing more than the rest of the TP $\left(+0.039^{\circ} \mathrm{C} \mathrm{yr}^{-1}\right)$. In general we observed an increase of meanT $\left(0.037^{\circ} \mathrm{C} \mathrm{yr}^{-1}\right)$ comparable to that reported by Yang et al. (2012) $\left(0.031^{\circ} \mathrm{C} \mathrm{yr}^{-1}\right)$ in the $1971-2007$ period.

At regional level, on the TP, the warming of minT is more prominent than that of maxT (e.g., Liu et al., 2006; Liu et al., 2009). In particular, for stations above $2000 \mathrm{~m}$ a.s.l. during the 1961-2003 period, Liu et al. (2006) found that $\operatorname{minT}$ trends were consistently greater $\left(+0.041{ }^{\circ} \mathrm{C} \mathrm{yr}^{-1}\right)$ than those of $\operatorname{maxT}\left(+0.018^{\circ} \mathrm{C} \mathrm{yr}^{-1}\right)$, especially in the winter and spring months. Yang et al. (2012), focusing their analysis on CH-N (which corresponds to the southern TP) in a more recent period (1971-2007), showed a significant increase of $+0.031{ }^{\circ} \mathrm{C} \mathrm{yr}^{-1}$ for meanT. Yang et al. (2006) analyzed five stations located in a more limited area of $\mathrm{CH}-\mathrm{N}$ : the north- 


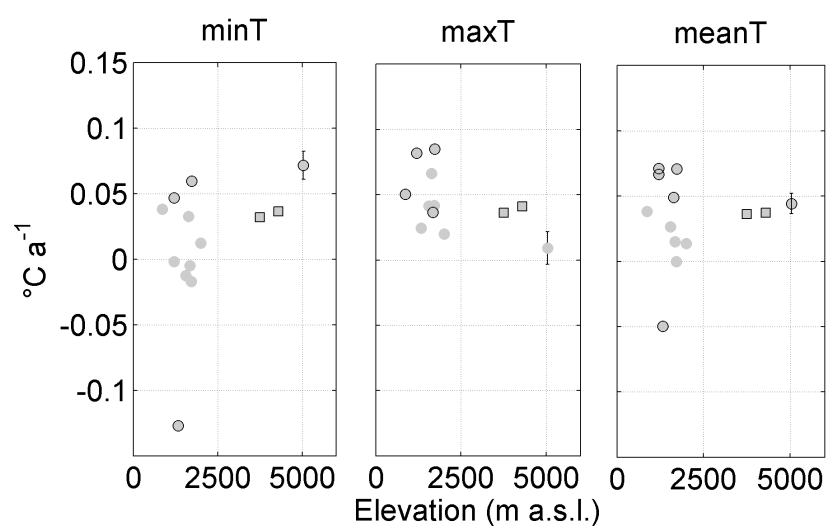

Figure 7. Elevation dependency of minimum (a), maximum (b), and mean (c) air temperatures with the Sen's slopes for the 1994 2013 period. The circle indicates stations with less than $10 \%$ of missing daily data, and the star indicates stations showing a trend with $p$-value $<0.1$. The red marker represents the trend and the associated uncertainty ( 2 standard deviations) referred to the reconstructed time series for the AWS1 station (PYRAMID). Data are reported in Table 2 .

ern side of Mt. Everest (therefore, including the two stations also considered in this study) from 1971 to 2004 . The warming is observed to be influenced more markedly by the minT increase.

In summary, PYRAMID shares the higher $T$ trends outside the monsoon period. However, in contrast with studies located south of the Himalayan ridge, which observed a prevalence of maxT increase, PYRAMID experienced a consistent minT increase $\left(+0.072^{\circ} \mathrm{C} \mathrm{yr}^{-1}\right.$ for PYRAMID vs. $+0.003{ }^{\circ} \mathrm{C} \mathrm{yr}^{-1}$ for KO-S stations), while the $\operatorname{maxT}$ increase is decidedly weaker $\left(+0.009^{\circ} \mathrm{C} \mathrm{yr}^{-1}\right.$ for PYRAMID vs. $+0.060^{\circ} \mathrm{C} \mathrm{yr}^{-1}$ for KO-S stations). The remarkable minT trend of PYRAMID is higher, but more similar to the pattern of change commonly described on the TP, in particular in $\mathrm{CH}-\mathrm{N}$, and also in this study $\left(+0.072{ }^{\circ} \mathrm{C} \mathrm{yr}^{-1}\right.$ for PYRAMID vs. $+0.034^{\circ} \mathrm{C} \mathrm{yr}^{-1}$ for KO-N stations), while the maxT increase is weaker $\left(+0.009^{\circ} \mathrm{C} \mathrm{yr}^{-1}\right.$ for PYRAMID vs. $+0.039^{\circ} \mathrm{C} \mathrm{yr}^{-1}$ for KO-N stations).

\subsection{Elevation dependency of temperature trends}

Figure 7 shows $T$ trends in the KO Basin for minT, meanT, and maxT relative to the elevation during the 1994-2013 period. No linear pattern emerges. However, we can observe the minT trend of the three stations located at higher altitude (PYRAMID and KO-N stations), which increases more than that of the lower stations (Fig. 7a, see also Table 2). Reviewing the most recent studies in the surroundings, we found that they are quite exclusively located on $\mathrm{CH}-\mathrm{N}$. These studies often show contradictory elevation dependencies (Rangwala and Miller, 2012). A recent study by You et al. (2010) did not find any significant elevation dependency in the warm- ing rates of meanT between 1961 and 2005. However, considering mostly the same stations, Liu et al. (2009) found that the warming rates for minT were greater at higher elevations. Observations from $\mathrm{CH}-\mathrm{S}$ are much rarer. Shrestha et al. (1999) found elevation dependency in the rate at which maxT were increasing in the Nepali Himalayas (CH-S), with higher rates at higher elevations, but this study exclusively considered stations under $3000 \mathrm{~m}$ a.s.l.

Furthermore we did not find for the Koshi Basin any significant elevation dependency in the weakening rates of Prec.

\subsection{Precipitation trends of the Koshi Basin compared to the regional pattern}

As will be detailed in the following, different from the north side of Mt. Everest and from the general TP, we confirm the general monsoon weakening on the KO-S, observing a substantial Prec decrease of $15 \%\left(-11.1 \mathrm{~mm} \mathrm{yr}^{-1},-222 \mathrm{~mm}\right)$, but that is not significant for all stations. At PYRAMID, the annual loss is relatively comparable with that of the KO-S $\left(-13.7 \mathrm{~mm} \mathrm{yr}^{-1},-273 \mathrm{~mm}\right)$, but at these high elevations, as we observed in Table 2, the weather is much more drier (449 and $1527 \mathrm{~mm}$, respectively). Therefore, the fractional loss is more than 3 times $(-52 \%)$ that of the KO-S. Considering that the decreasing trend observed during the summer is more robust than the annual one (see above), the fractional loss of Prec during the monsoon is $-47 \%$, which means that currently, on average, the precipitation at PYRAMID is the half of what it was 20 years ago.

At regional level, Turner and Annamalai (2012), using the all-India rainfall data based on a weighted mean of 306 stations, observed a negative precipitation trend since the 1950s in South Asia. According to Yao et al. (2012), using the Global Precipitation Climatology Project (GPCP) data, there is strong evidence that precipitation from 1979 to 2010 decreased even in the Himalayas. In eastern $\mathrm{CH}-\mathrm{S}$, where the Koshi Basin is located, they estimated a loss of $173 \mathrm{~mm}$, showing a real decreasing trend starting from the early 1990s (mean value between grid 9 and 11 in Fig. S18 of their paper).

On the TP, the observed pattern of change is opposite that of the monsoon weakening described by the authors cited above. Liu et al. (2010) described an increase in precipitation in CH-N for the period of the 1980s to 2008. Su et al. (2006) described a marked precipitation increase in the Yangtze River Basin (eastern $\mathrm{CH}-\mathrm{N}$ ). In a similar way to the $T$ analysis, Yang et al. (2006) considered five stations located on the northern side of Mt. Everest (therefore, including the two stations also considered in this study) from 1971 to 2004 and observed an increasing, but not significant Prec trend. The higher stationarity we observed is confirmed since 1971 for the two KO-N stations considered in this study. 


\subsection{Mechanisms responsible for temperature warming and precipitation weakening}

According to Rangwala and Miller (2012), there are a number of mechanisms that can cause enhanced warming rates at high elevation, and they often have strong seasonal dependency. These mechanisms arise from either elevation-based differential changes in climate drivers, such as snow cover, clouds, specific humidity, aerosols, and soil moisture, or differential sensitivities of surface warming to changes in these drivers at different elevations. This study does not aim to either realize a comprehensive review or to demonstrate the causes that could have led to the climate change pattern observed at PYRAMID, but our intent here is just to note the recent hypotheses advanced in the literature that fit with our observations for the region of investigation.

Snow/ice albedo is one of the strongest feedbacks in the climate system (Rangwala and Miller, 2012). Increases in minT are possible if decreases in snow cover are accompanied by increases in soil moisture and surface humidity, which can facilitate a greater diurnal retention of the daytime solar energy in the land surface and amplify the longwave heating of the land surface at night (Rangwala et al., 2012). For the Tibetan Plateau, Rikiishi and Nakasato (2006) found that the length of the snow cover season declined at all elevations between 1966 and 2001. Moreover, minT can be enhanced by nighttime increases in cloud cover. However, assessing changes in clouds and quantifying cloud feedbacks will remain challenging in the near term. For the Tibetan Plateau, Duan and Wu (2006) found that low level nocturnal cloud cover increased over the TP between 1961 and 2003 and that these increases explain part of the observed increases in $\min T$.

The maxT increase observed here during April $(p<0.05$ in 2011, Fig. 4b) fits with the warming reported by Pal and Al-Tabbaa (2010) which observed that within the premonsoon season only April shows significant changes in maxT in all Indian regions and WH (1901-2003 period). According to Ramanathan et al. (2007), Gautam et al. (2010) argued that the observed warming during the pre-monsoon period (April-June) can be ascribed not only to the global greenhouse warming, but also to the solar radiation absorption caused by the large amount of aerosol (mineral dust mixed with other carbonaceous material) transported over the Gangetic-Himalayan region. As recently reported by Marinoni et al. (2013), April represents the month for which the transport of absorbing carbonaceous aerosol (i.e. black carbon) is maximized in our region of investigation (Khumbu Valley). Regarding this, Putero et al. (2013) show evidence for a possible influence of open fire occurrence in South Asia particularly abundant during this period of the year. However the significant decreasing of maxT observed in May $(p<0.05)$ and the slight significant decreasing during the monsoon months from June to August $(p<0.10)$ appear to deviate from the scenario proposed for April. In this respect

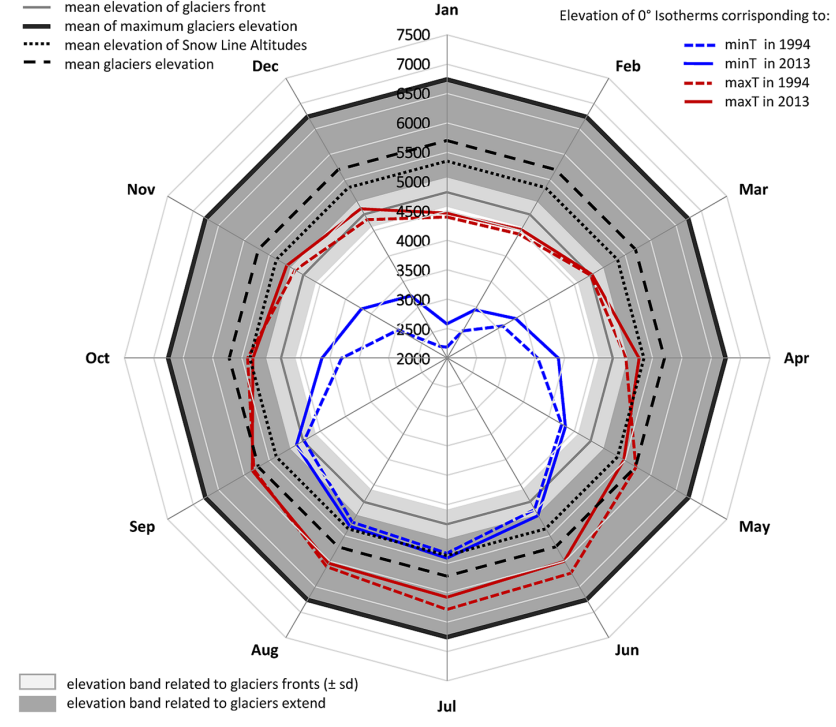

Figure 8. Linkage between the temperature increases and altitudinal glacier distribution. The $0{ }^{\circ} \mathrm{C}$ isotherms corresponding to the mean monthly minimum and maximum temperature are plotted for the 1994 and 2013 years according the observed T trends and lapse rates.

it should be kept in mind that the radioactive dynamical interactions of aerosol with the monsoon cycle are extremely complex and different processes can interact with each other. As an instance, as reported by Qian et al. (2011), the deposition of absorbing aerosol on snow and the snow albedo feedback processes can play a prominent role in Himalayas and TP inducing large radioactive flux changes and surface temperature perturbation.

Recent studies associate the precipitation decrease over India during the second half of 20th century (e.g., Ramanathan et al., 2005; Lau and Kim, 2006) to the significant tropospheric warming over the tropical area from the Indian Ocean to the western Pacific (e.g., Wu, 2005), while westerlies are strengthening (Zhao et al., 2012). Other authors (e.g., Bollasina et al., 2011) attribute the monsoon weakening to human-influenced aerosol emissions. In fact an increase of aerosols over South Asia has been well documented (Ramanathan et al., 2005; Lau and Kim, 2006) and climate model experiments suggest that sulfate aerosol may significantly reduce monsoon precipitation (Mitchell and Johns, 1997). Despite a historical weakening of the monsoon circulation, most studies project an increase of the seasonal monsoon rainfall under global warming. Regarding this Levy II et al. (2013) find that the dramatic emission reductions (35$80 \%$ ) in anthropogenic aerosols and their precursors projected by a representative concentration pathway (RCP) 4.5 (Moss et al., 2010) result an increasing trend by the second half of the 21st century in South Asia and in particular over the Himalaya (Palazzi et al., 2013). 


\subsection{Linking climate change patterns observed at high elevation with glacier responses}

\subsubsection{Impact of temperature increase}

Air temperature and precipitation are the two factors most commonly related to glacier fluctuations. However, there still exists a seasonal gap in order to explain the shrinking of summer accumulation-type glaciers (typical of $\mathrm{CH}$ ) due to large temperature increases observed in the region during winter (Ueno and Aryal, 2008), as is the case for the south slopes of Mt. Everest. Furthermore, in this study we noted a slightly significant decline in summer maxT and stationary meanT. The real increase of $\mathrm{T}$ has been observed for minT, but given the mean elevation of glaciers $(5695 \mathrm{~m}$ a.s.l. in $1992)$ and the mean elevation range of glacier fronts (4568$4817 \mathrm{~m}$ a.s.l. in 1992 , mean $4817 \mathrm{~m}$ a.s.l., $249 \mathrm{~m}$ of standard deviation: sd) (Thakuri et al., 2014), this increase for minT can be most likely considered ineffective for melting processes, since $T$ is still less than $0{ }^{\circ} \mathrm{C}$. This inference can be ascertained analyzing Fig. 8, created in order to link temperature increases and altitudinal glacier distribution (data from Thakuri et al., 2014). The $0{ }^{\circ} \mathrm{C}$ isotherms, corresponding to the mean monthly minT and maxT, are plotted for 1994 and 2013. The elevation of each $0^{\circ} \mathrm{C}$ isotherm is calculated according to the accurate lapse rates computation carried out in this study and the observed monthly $T$ trends. We can note that in 1994 the $0^{\circ} \mathrm{C}$ isotherm for minT reached the elevation band characterizing the glacier fronts only from June to September. However, 20 years later, the upward movement of the $0{ }^{\circ} \mathrm{C}$ isotherm is modest $(+92 \mathrm{~m})$ during these months, compared to the huge but ineffective rise for melting processes (downstream from the glacier fronts) of DecemberNovember (even $+854 \mathrm{~m})$. The maxT has obviously a greater potential impact on glaciers. In fact the $0^{\circ} \mathrm{C}$ isotherm for of all months except January and February crosses the elevation bands within which the glacier fronts are located ever since 1994. In this regard, we observe that only April $(+224 \mathrm{~m})$, December $(+212 \mathrm{~m})$, and November $(+160 \mathrm{~m})$ experienced an upward of the $0^{\circ} \mathrm{C}$ isotherm able to enhance the melting processes, but only close to the glaciers fronts. We therefore point out that the impact caused by the increased temperature occurring in April most likely plays an important role not only in relation to this case study, but also at the level of the Himalayan range. In fact, as mentioned above, Pal and AlTabbaa (2010), observed that within the pre-monsoon season, only April showed significant changes in maxT in all Indian regions and WH (1901-2003 period).

\subsubsection{Impact of precipitation decrease}

Regarding the precipitation, in this study we noted a strong and significant decreasing Prec trend for all months, corresponding to a fractional loss of $47 \%$ during the monsoon season which indicates that, on average, the precipitation at

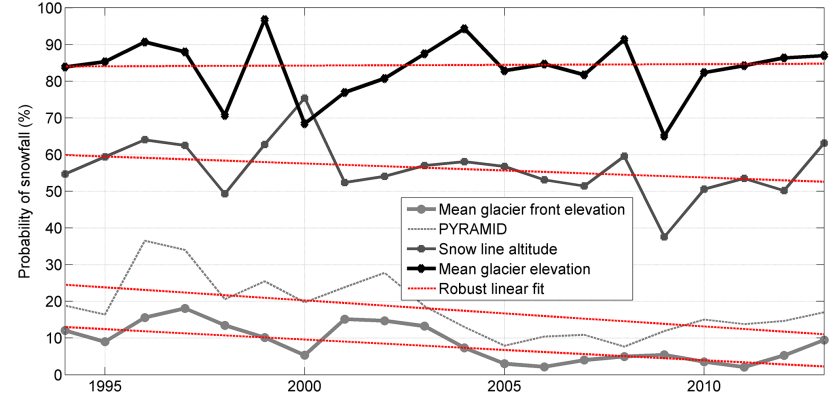

Figure 9. Trend analysis of annual probability of snowfall on total cumulated precipitation. The red lines represents the robust linear fitting of the time series characterized by the associated Sen's slope (more details in the caption of Fig. 3).

PYRAMID is currently half of what it was 20 years ago. This climate change pattern confirms and clarifies the observation of Thakuri et al. (2014), who noted that the southern Mt. Everest glaciers experienced a shrinkage acceleration over the last 20 years (1992-2011), as underlined by an upward shift of SLA with a velocity almost 3 times greater than the previous period (1962-1992). The authors, without the support of climatic data, proposed the hypothesis that Mt. Everest glaciers are shrinking faster since the early 1990s mainly as a result of a weakening of precipitation over the last decades. In fact they observed a double upward shift in the SLA of the largest glaciers (south-oriented and with a higher altitude accumulation zone): a clear signal of a significant decrease in accumulation. Wagnon et al. (2013) have recently reached the same conclusion, but also in this case without the support of any climatic studies. Bolch et al. (2011) and Nuimura et al. (2012) registered a higher mass loss rate during the last decade (2000-2010).

Furthermore Quincey et al. (2009) and Peters et al. (2010) observed lower glacier flow velocity in the region over the last decades. Many studies highlight how the present condition of ice stagnation of glaciers in the Mt Everest region, and in general in $\mathrm{CH}-\mathrm{S}$, is attributable to low flow velocity generated by generally negative mass balances (Bolch et al., 2008; Quincey et al., 2009; Scherler et al., 2011). Our observations allow attributing the lower glacier flow velocity to lower accumulation due to weaker precipitation, which can thus be considered the main climatic factor driving the current ice stagnation of tongues. In this regard we need to keep in mind that changes in velocity are among the main triggers for the formation of supraglacial and proglacial lakes (Salerno et al., 2012; Quincey et al., 2009), which we know to be susceptible to GLOFs.

\subsubsection{Trend analysis of annual probability of snowfall}

Figure 9 analyzes how the changes observed for the meanT at PYRAMID have affected the probability of snowfall on total cumulated annual precipitation in the last 20 years. 
The increase of meanT observed outside the monsoon period, when the precipitation is almost completely composed by snow (Fig. 2), brought a significant decrease of solid phase $\left(+0.7 \% \mathrm{yr}^{-1}, p<0.05\right)$. Extending this analysis to the elevation bands characterizing the glaciers distribution (see Fig. 8), through the temperature lapse rate calculated here, we observe that at the level of the mean glaciers (5695 ma.s.1.) the probability of snowfall is stationary $\left(+0.04 \% \mathrm{yr}^{-1}\right)$, while it decreases at the mean elevation of SLAs (5345 ma.s.l. in 1992, Thakuri et al., 2014), but not significantly $\left(-0.38 \% \mathrm{yr}^{-1}, p>0.1\right)$. The reduction becomes significant at lower altitudes. In particular, at the mean elevation of glacier fronts $(4817 \mathrm{~m}$ a.s.1.) the probability of snowfall is $-0.56 \% \mathrm{yr}^{-1}(p<0.05)$; i.e. at these altitudes the probability of snow on annual base is currently $11 \%(p<0.05)$ less than 20 years ago. We can conclude this analysis summarizing that a significant change in precipitation phase has occurred close to the terminal portions of glaciers, corresponding broadly to the glaciers ablation zones (around $10 \%, p<0.5$ ), while the lower temperature of the upper glaciers zones has so far guaranteed a stationary condition.

\section{Conclusions}

Most relevant studies on temperature trends were conducted on the Tibetan Plateau, the Indian subcontinent (including the WH) and the Upper Indus Basin, while studies on the mountainous regions along the southern slope of the central Himalayas in Nepal (CH-S) are limited. Although Shrestha et al. (1999) analyzed the maximum temperature trends over Nepal during the period 1971-1994, studies on recent temperature trends over $\mathrm{CH}-\mathrm{S}$ are still lacking and, before this study, completely absent as regards high elevation. This paper addresses seasonal variability of minimum, maximum, and mean temperatures and precipitation at high elevation on the southern slopes of Mt. Everest. Moreover, we complete this analysis with data from all the existing weather stations located on both sides of the Himalayan range (Koshi Basin) for the 1994-2013 period, during which a more rapid glacier mass loss occurred.

At high elevation on the southern slopes of Mt. Everest, we observed the following.

1. The main increases in air temperature are almost completely concentrated during the post-monsoon months. The pre-monsoon period experienced a slighter and insignificant increase, while the monsoon season is generally stationary. This seasonal temperature change pattern is shared with the entire Koshi Basin, and it is also observed in the regional studies related to the northern and southern slopes of the Himalayan range. Surprisingly, above $5000 \mathrm{~m}$ a.s.l. the maximum temperature decreases significantly in May and slightly during the monsoon months from June to August. (a) The minimum temperature increased much more than the maximum temperature. This remarkable minimum temperature trend is more similar to the pattern of change commonly described on the Tibetan Plateau and confirmed in this study in the northern Koshi Basin. However, this trend is in contrast with studies located south of the Himalayan ridge. As proved by this study, the southern Koshi Basin experienced a prevalence of maximum temperature increases. No linear pattern emerges in the elevation dependency of temperature trends. We only observed higher minimum temperature trends at higher altitudes.

(b) The total annual precipitation has considerably decreased. The annual rate of decrease above $5000 \mathrm{~m}$ a.s.1. is similar to the one at lower altitudes on the southern side of the Koshi Basin, but the drier conditions of this remote environment make the fractional loss relatively more consistent. The precipitation at high elevation during the monsoon period is currently half of what it was 20 years ago. These observations confirm the monsoon weakening observed by previous studies in India and even in the Himalayas since the early 1980s. As opposed to the northern side of the Koshi Basin that shows in this study certain stability, as positive or stationary trends have been observed by previous studies on the TP and more specifically in northern central Himalaya.

2. There is a significantly lower probability of snowfall in the glaciers ablation zones, while the lower temperature of the upper glaciers zones have so far guaranteed a stationary condition.

In general, this study contributes to change the perspective on how the climatic driver (temperature vs. precipitation) led the glacier responses in the last 20 years.

Without demonstrating the causes that could have led to the climate change pattern observed at the PYRAMID, we simply note the recent literature on hypotheses that are in accordance with our observations.

In conclusion, we have here observed that weather stations at low elevations are not able to suitably describe the climate changes occurring above $5000 \mathrm{~m}$ a.s.l. and thus correctly interpret the impact observed on the cryosphere. This consideration stresses the great importance of long-term ground measurements at high elevation.

\section{The Supplement related to this article is available online at doi:10.5194/tc-9-1229-2015-supplement.}


Author contributions. G. Tartari, Y. Ma and E. Vuillermoz designed research; F. Salerno performed research; F. Salerno, N. Guyennon, S. Thakuri, G. Viviano and E. Romano analyzed data; F. Salerno, N. Guyennon, E. Romano and G. Tartari wrote the paper. P. Cristofanelli, P. Stocchi, N. Guyennon and G. Agrillo data quality check.

Acknowledgements. This work was supported by the MIUR through Ev-K2-CNR/SHARE and CNR-DTA/NEXTDATA project within the framework of the Ev-K2-CNR and Nepal Academy of Science and Technology (NAST). Sudeep Thakuri is recipient of the IPCC Scholarship Award under the collaboration between the IPCC Scholarship Programme and the Prince Albert II of Monaco Foundation's Young Researchers Scholarships Initiative.

Edited by: V. Radic

\section{References}

Abebe, A., Solomatine, D., and Venneker, R.: Application of adaptive fuzzy rule based models for reconstruction of missing precipitation events, Hydrolog. Sci. J., 45, 425-436, doi:10.1080/02626660009492339, 2000.

Abudu, S., Bawazir, A. S., and King, J. P.: Infilling missing daily evapotranspiration data using neural networks, J. Irrig. Drain. E-ASCE, 136, 317-325, doi:10.1061/(ASCE)IR.19434774.0000197, 2010.

Amatya, L. K., Cuccillato, E., Haack, B., Shadie, P., Sattar, N., Bajracharya, B., Shrestha, B., Caroli, P., Panzeri, D., Basani, M., Schommer, B., Flury, B., Salerno, F., and Manfredi, E. C.: Improving communication for management of social-ecological systems in high mountain areas: Development of methodologies and tools - The HKKH Partnership Project, Mt. Res. Dev., 30, 69-79, doi:10.1659/MRD-JOURNAL-D-09-00084.1, 2010.

Bajracharya, B., Uddin, K., Chettri, N., Shrestha, B., and Siddiqui, S. A.: Understanding land cover change using a harmonized classification system in the Himalayas: A case study from Sagarmatha National Park, Nepal, Mt. Res. Dev., 30, 143-156, doi:10.1659/MRD-JOURNAL-D-09-00044.1, 2010.

Barros, A. P., Kim, G., Williams, E., and Nesbitt, S .W.: Probing orographic controls in the Himalayas during the monsoon using satellite imagery, Nat. Hazards Earth Syst. Sci., 4, 29-51, doi:10.5194/nhess-4-29-2004, 2004.

Benn, D. I., Bolch, T., Hands, K., Gulley, J., Luckman, A., Nicholson, L. I., Quincey, D., Thompson, S., Toumi, R., and Wiseman, S.: Response of debris-covered glaciers in the Mount Everest region to recent warming, and implications for outburst flood hazards, Earth-Sci. Rev., 114, 156-174, doi:10.1016/j.earscirev.2012.03.008, 2012.

Bertolani L., Bollasina, M., and Tartari, G.: Recent biannual variability of meteorological features in the Eastern Highland Himalayas, Geophys. Res. Lett., 27, 2185-2188, doi:10.1029/1999GL011198, 2000.

Bhutiyani, M. R., Kale, V. S., and Pawar, N. J.: Long-term trends in maximum, minimum and mean annual air temperatures across the Northwestern Himalaya during the twentieth century, Clim. Change, 85, 159-177, doi:10.1007/s10584-006-9196-1, 2007.
Bocchiola, D. and Diolaiuti, G.: Evidence of climate change within the Adamello Glacier of Italy, Theor. Appl. Climatol., 100, 351369, doi:10.1007/s00704-009-0186-x, 2010.

Bolch, T., Buchroithner, M., Pieczonka, T., and Kunert, A.: Planimetric and volumetric glacier changes in the Khumbu Himal, Nepal, since 1962 using Corona, Landsat TM and ASTER data, J. Glaciol., 54, 592-600, doi:0.3189/002214308786570782, 2008.

Bolch, T., Kulkarni, A., Kääb, A., Huggel, C., Paul, F., Cogley, J. G., Frey, H., Kargel, J. S., Fujita, K., Scheel, M., Bajracharya, S., and Stoffel, M.: The state and fate of Himalayan glaciers, Science, 336, 310-314, doi:10.1126/science.1215828, 2012.

Bolch, T., Pieczonka, T., and Benn, D. I.: Multi-decadal mass loss of glaciers in the Everest area (Nepal Himalaya) derived from stereo imagery, The Cryosphere, 5, 349-358, doi:10.5194/tc-5349-2011, 2011.

Bollasina, M. A., Ming, Y., and Ramaswamy, V.: Anthropogenic aerosols and the weakening of the south Asian summer monsoon, Science, 334, 502-505, doi:10.1126/science.1204994, 2011.

Bookhagen, B. and Burbank, D. W.: Topography, relief, and TRMM-derived rainfall variations along the Himalaya, Geophys. Res. Lett., 33, L08405, doi:10.1029/2006GL026037, 2006.

Carraro, E., Guyennon, N., Hamilton, D., Valsecchi, L., Manfredi, E. C., Viviano, G., Salerno, F., Tartari, G., and Copetti, D.: Coupling high-resolution measurements to a three-dimensional lake model to assess the spatial and temporal dynamics of the cyanobacterium Planktothrix rubescens in a medium-sized lake, Hydrobiologia, 698, 77-95, doi:10.1007/s10750-012-1096y, 2012.

Carraro, E., Guyennon, N., Viviano, G., Manfredi, E. C., Valsecchi, L., Salerno, F., Tartari, G., and Copetti, D.: Impact of Global and Local Pressures on the Ecology of a Medium-Sized PreAlpine Lake, in Models of the Ecological Hierarchy, edited by: Jordan, F. and Jorgensen, S. E., Elsevier B.V., 259-274, doi:10.1016/B978-0-444-59396-2.00016-X, 2012 b.

Coulibaly, P. and Evora, N.: Comparison of neural network methods for infilling missing daily weather records, J. Hydrol., 341, 27 41, doi:10.1016/j.jhydrol.2007.04.020, 2007.

D'équé, M.: Frequency of precipitation and temperature extreme over France in an anthropogenic scenario: model results and statistical correction according to observed values, Global Planet. Change, 57, 16-26, doi:10.1016/j.gloplacha.2006.11.030, 2007.

Duan, A. and Wu, G.: Change of cloud amount and the climate warming on the Tibetan Plateau, Geophys. Res. Lett., 33, L22704, doi:10.1029/2006GL027946, 2006.

Dytham, C.: Choosing and Using Statistics: A Biologist's Guide, John Wiley \& Sons, 2011.

Fujita, K. and Sakai, A.: Modelling runoff from a Himalayan debris-covered glacier, Hydrol. Earth Syst. Sci., 18, 2679-2694, doi:10.5194/hess-18-2679-2014, 2014.

Fujita, K., Sakai, A., Takenaka, S., Nuimura, T., Surazakov, A. B., Sawagaki, T., and Yamanokuchi T.: Potential flood volume of Himalayan glacial lakes, Nat. Hazards Earth Syst. Sci., 13, 18271839, doi:10.5194/nhessd-1-15-2013, 2013.

Gardelle, J., Arnaud, Y., and Berthier, E.: Contrasted evolution of glacial lakes along the Hindu Kush Himalaya mountain range between 1990 and 2009, Global Planet. Change, 75, 47-55, doi:10.1016/j.gloplacha.2010.10.003, 2011. 
Gautam, R., Hsu, N. C., and Lau, K. M.: Premonsoon aerosol characterization and radiative effects over the Indo-Gangetic plains: implications for regional climate warming, J. Geophys. Res., 115, D17208, doi:10.1029/2010JD013819, 2010.

Gerstengarbe, F. W. and Werner, P. C.: Estimation of the beginning and end of recurrent events within a climate regime, Clim. Res., 11, 97-107, 1999.

Guyennon, N., Romano, E., Portoghese, I., Salerno, F., Calmanti, S., Petrangeli, A. B., Tartari, G., and Copetti, D.: Benefits from using combined dynamical-statistical downscaling approaches - lessons from a case study in the Mediterranean region, Hydrol. Earth Syst. Sc., 17, 705-720, doi:10.5194/hess-17-7052013, 2013.

Hock, R.: Glacier melt: a review of processes and their modeling, Prog. Phys. Geog., 29, 362-391, doi:10.1191/0309133305pp453ra, 2005.

Ichiyanagi, K., Yamanaka, M. D., Muraji, Y., and Vaidya, B. K.: Precipitation in Nepal between 1987 and 1996, Int. J. Climatol., 27, 1753-1762, doi:10.1002/joc.1492, 2007.

Immerzeel, W. W., Petersen, L., Ragettli, S., and Pellicciotti, F.: The importance of observed gradients of air temperature and precipitation for modeling runoff from a glacierized watershed in the Nepal Himalayas, Water Resour. Res., 50, 2212-2226, doi:10.1002/2013WR014506, 2014.

James, A. L. and Oldenburg, C. M.: Linear and Monte Carlo uncertainty analysis for subsurface contaminant transport simulation, Water Resour. Res., 33, 2495-2508, doi:10.1029/97WR01925, 1997.

Kattel, D. B. and Yao, T.: Recent temperature trends at mountain stations on the southern slope of the central Himalayas, J. Earth Syst. Sci., 122, 215-227, doi:10.1007/s12040-012-0257-8, 2013.

Kattel, D. B., Yao, T., Yang, K., Tian, L., Yang, G., and Joswiak, D.: Temperature lapse rate in complex mountain terrain on the southern slope of the central Himalayas, Theor. Appl. Climatol., 113, 671-682, doi:10.1007/s00704-012-0816-6, 2013.

Kendall, M. G.: Rank Correlation Methods, Oxford University Press, New York, 1975.

Lami, A., Marchetto, A., Musazzi, S., Salerno, F., Tartari, G., Guilizzoni, P., Rogora, M., and Tartari, G. A.: Chemical and biological response of two small lakes in the Khumbu Valley, Himalayas (Nepal) to short-term variability and climatic change as detected by long-term monitoring and paleolimnological methods, Hydrobiologia, 648, 189-205, doi:10.1007/s10750-010-0262-3, 2010.

Lau, K.-M. and Kim, K.-M.: Observational relationships between aerosol and Asian monsoon rainfall, and circulation, Geophys. Res. Lett., 33, L21810, doi: 10.1029/2006GL027546, 2006.

Lavagnini, I., Badocco, D., Pastore, P., and Magno, F.: Theil-Sen nonparametric regression technique on univariate calibration, inverse regression and detection limits, Talanta, 87, 180-188, doi:10.1016/j.talanta.2011.09.059, 2011.

Levy II, H., Horowitz, L. W., Schwarzkopf, M. D., Ming, Y., Golaz, J. C., Naik, V., and Ramaswamy, V.: The roles of aerosol direct and indirect effects in past and future climate change, J. Geophys. Res., 118, 1-12, doi:10.1002/jgrd.50192, 2013.

Liu, J., Yang, B., and Qin, C.: Tree-ring based annual precipitation reconstruction since AD 1480 in south central Tibet, Quatern. Int., 236, 75-81, doi:10.1016/j.quaint.2010.03.020, 2010.

Liu, K., Cheng, Z., Yan, L., and Yin, Z.: Elevation dependency of recent and future minimum surface air temperature trends in the
Tibetan Plateau and its surroundings, Global Planet. Change, 68, 164-174, doi:10.1016/j.gloplacha.2009.03.017, 2009.

Liu, X. D., Yin, Z. Y., Shao, X., and Qin, N.: Temporal trends and variability of daily maximum and minimum, extreme temperature events, and growing season length over the eastern and central Tibetan Plateau during 1961-2003, J. Geophys. Res., 111, 1-19, doi:10.1029/2005JD006915, 2006.

Manfredi, E. C., Flury, B., Viviano, G., Thakuri, S., Khanal, S. N., Jha, P. K., Maskey, R. K., Kayastha, R. B., Kafle, K. R., Bhochhibhoya, S., Ghimire, N. P., Shrestha, B. B., Chaudhary, G., Giannino, F., Carteni, F., Mazzoleni, S., and Salerno, F.: Solid waste and water quality management models for Sagarmatha National Park and Buffer Zone, Nepal: implementation of a participatory modeling framework, Mt. Res. Dev., 30, 127-142, doi:10.1659/MRD-JOURNAL-D-10-00028.1, 2010.

Marinoni, A., Cristofanelli, P., Laj, P., Putero, D., Calzolari, F., Landi, T. C., Vuillermoz, E., Maione, M., and Bonasoni, P.: High black carbon and ozone concentrations during pollution transport in the Himalayas: Five years of continuous observations at NCO-Prec global GAW station, J. Environ. Sci., 25, 1618-1625, doi:10.1016/S1001-0742(12)60242-3, 2013.

Menne, M. J., Durre, I., Vose, R. S., Gleason, B. E., and Houston, T. G.: An overview of the Global Historical Climatology Network daily database, J. Atmos. Oceanic. Technol., 29, 897-910, 2012.

Mitchell, J. F. B. and Johns, T. C.: On the modification of global warming by sulphate aerosols, J. Climate, 10, 245-267, 1997.

Montgomery, D. R. and Stolar, D. B.: Reconsidering Himalayan river anticlines, Geomorphology, 82, 4-15, doi:10.1016/j.geomorph.2005.08.021, 2006.

Moss, R. H., Edmonds, J. A., Hibbard, K. A., Manning, M. R., Rose, S. K., van Vuuren, D. P., Carter, T. R., Emori, S., Kainuma, M. Kram, T., Meehl, G. A., Mitchell, J. F. B., Nakicenovic, N., Riahi, K., Smith, S. J., Stouffer, R. J., Thomson, A. M., Weyant, J. P., and Wilbank, T. J.: The next generation of scenarios for climate change research and assessment, Nature, 463, 747-756, doi:10.1038/nature08823, 2010.

Nuimura, T., Fujita, K., Yamaguchi, S., and Sharma, R. R.: Elevation changes of glaciers revealed by multitemporal digital elevation models calibrated by GPS survey in the Khumbu region, Nepal Himalaya, 1992-2008, J. Glaciol., 58, 648-656, doi:10.3189/2012JoG11J061, 2012.

Pal, I. and Al-Tabbaa, A.: Long-term changes and variability of monthly extreme temperatures in India, Theor. Appl. Climatol., 100, 45-56, doi:10.1007/s00704-009-0167-0, 2010.

Palazzi, E., von Hardenberg, J., and Provenzale, A.: Precipitation in the Hindu-Kush Karakoram Himalaya: Observations and future scenarios, J. Geophys. Res., 118, 85-100, 2013.

Pepin, N. C. and Lundqist, J. D.: Temperature trends at high elevations: patterns across the globe, Geophys. Res. Lett., 35, L14701, doi:10.1029/2008GL034026, 2008.

Peters, J., Bolch, T., Buchroithner, M. F., and Bäßler, M.: Glacier Surface Velocities in the Mount Everest Area/Nepal using ASTER and Ikonos imagery, Proceeding of 10th International Symposium on High Mountain Remote Sensing Cartography, Kathmandu, Nepal, 313-320, 2010.

Putero, D., Landi, T. C., Cristofanelli, P., Marinoni, A., Laj, P., Duchi, R., Calzolari, F., Verza, G. P., and Bonasoni, P.: Influence of open vegetation fires on black carbon and ozone variability in 
the southern Himalayas (NCO-P, 5079 m a.s.1.), Environ. Pollut., 184, 597-604, doi:10.1016/j.envpol.2013.09.035, 2013.

Qian, Y., Flanner, M., Leung, L., and Wang, W.: Sensitivity studies on the impacts of Tibetan plateau snowpack pollution on the Asian hydrological cycle and monsoon climate, Atmos. Chem. Phys., 11, 1929-1948, doi:10.5194/acp-11-1929-2011, 2011.

Quincey, D. J., Luckman, A., and Benn, D.: Quantification of Everest region glacier velocities between 1992 and 2002, using satellite radar interferometry and feature tracking, J. Glaciol., 55, 596-606, doi:10.3189/002214309789470987, 2009.

Ramanathan, V., Chung, C., Kim, D., Bettge, T., Buja, L., Kiehl, J. T., Washington, W. M., Fu, Q., Sikka, D. R., and Wild, M.: Atmospheric brown clouds: Impacts on South Asian climate and hydrological cycle. Proc. Natl. Acad. Sci. USA, 102, 5326-5333, doi:10.1073/pnas.0500656102, 2005.

Ramanathan, V., Li, F., Ramana, M. V., Praveen, P. S., Kim, D., Corrigan, C. E., Nguyen, H., Stone, E. A., Schauer, J. J., Carmichael, G. R., Adhikary, B., and Yoon, S. C.: Atmospheric brown clouds: Hemispherical and regional variations in long-range transport, absorbtion, and radiative forcing, J. Geophys. Res., 112, D22S21, doi:10.1029/2006JD008124, 2007.

Rangwala, I. and Miller, J. R.: Climate change in mountains: a review of elevation-dependent warming and its possible causes, Clim. Change, 114, 527-547, doi:10.1007/s10584-012-0419-3, 2012

Rangwala, I., Barsugli, J., Cozzetto, K., Neff, J., and Prairie, J.: Mid-21st century projections in temperature extremes in the southern Colorado Rocky Mountains from regional climate models, Clim. Dynam., 39, 1823-1840, doi:10.1007/s00382-0111282-z, 2012.

Rikiishi, K. and Nakasato, H.: Height dependence of the tendency for reduction in seasonal snow cover in the Himalaya and the Tibetan Plateau region, 1966-2001, Ann. Glaciol., 43, 369-377, doi:10.3189/172756406781811989, 2006.

Salerno, F., Buraschi, E., Bruccoleri, G., Tartari, G., and Smiraglia, C.: Glacier surface-area changes in Sagarmatha National Park, Nepal, in the second half of the 20th century, by comparison of historical maps, J. Glaciol., 54, 738-752, 2008.

Salerno, F., Cuccillato, E., Caroli, P., Bajracharya, B., Manfredi, E. C., Viviano, G., Thakuri, S., Flury, B., Basani, M., Giannino, F., and Panzeri, D.: Experience with a hard and soft participatory modeling framework for social ecological system management in Mount Everest (Nepal) and K2 (Pakistan) protected areas, Mt. Res. Dev., 30, 80-93, 2010a.

Salerno, F., Gambelli, S., Viviano, G., Thakuri, S., Guyennon, N., D’Agata, C., Diolaiuti, G., Smiraglia, C., Stefani, F., Bochhiola, D., and Tartari, G.: High alpine ponds shift upwards as average temperature increase: A case study of the Ortles-Cevedale mountain group (Southern alps, Italy) over the last 50 years, Global Planet. Change,120, 81-91, doi:10.1016/j.gloplacha.2014.06.003, 2014.

Salerno, F., Thakuri, S., D’Agata, C., Smiraglia, C., Manfredi, E. C., Viviano, G., and Tartari, G.: Glacial lake distribution in the Mount Everest region: Uncertainty of measurement and conditions of formation, Global Planet. Change, 92-93, 30-39, doi:10.1016/j.gloplacha.2012.04.001, 2012.

Salerno, F., Viviano, G., Mangredi, E. C., Caroli, P., Thakuri, S., and Tartari, G.: Multiple Carrying Capacities from a management-oriented perspective to operationalize sustainable tourism in protected area, J. Environ. Manage., 128, 116-125, doi:10.1016/j.jenvman.2013.04.043, 2013.

Salerno, F., Viviano, G., Thakuri, S., Flury, B., Maskey, R. K., Khanal, S. N., Bhuju, D., Carrer, M., Bhochhibhoya, S., Melis, M. T., Giannino, F., Staiano, A., Carteni, F., Mazzoleni, S., Cogo, A., Sapkota, A., Shrestha, S., Pandey, R. K., and Manfredi, E. C.: Energy, forest, and indoor air pollution models for Sagarmatha National Park and Buffer zone, Nepal: implementation of a participatory modeling framework, Mt. Res. Dev., 30, 113-126, 2010b.

Scherler, D., Bookhagen, B., and Strecker, M. R.: Spatially variable response of Himalayan glaciers to climate change affected by debris cover, Nat. Geosci., 4, 156-159, doi:10.1038/ngeo1068, 2011.

Schneider, T.: Analysis of incomplete climate data: Estimation of mean values and covariance matrices and imputation of missing values, J. Climate, 14, 853-871, doi:10.1175/15200442(2001)014<0853:AOICDE> 2.0.CO;2, 2001.

Sen, P. K.: Estimates of the regression coefficient based on Kendall's Tau, J. Am. Assoc., 63, 1379-1389, doi:10.2307/2285891, 1968.

Shekhar, M. S., Chand, H., Kumar, S., Srinivasan, K., and Ganju, A.: Climate-change studies in the western Himalaya, Ann. Glaciol., 51, 105-112, doi:10.3189/172756410791386508, 2010.

Shrestha, A. B., Wake, C. P., Mayewski, P. A., and Dibb, J. E.: Maximum temperature trends in the Himalaya and its vicinity: An analysis based on temperature records from Nepal for the period 1971-94, J. Climate, 12, 2775-5561, doi:10.1175/15200442(1999)012<2775:MTTITH>2.0.CO;2, 1999.

Singh, P. and Kumar, N.: Effect of orography on precipitation in the western Himalayan region, J. Hydrol., 199, 183-206, doi:10.1016/S0022-1694(96)03222-2, 1997.

Su, B. D., Jiang, T., and Jin, W. B.: Recent trends in observed temperature and precipitation extremes in the Yangtze River basin, China, Theor. Appl. Climatol., 83, 139-151, doi:10.1007/s00704-005-0139-y, 2006.

Tartari, G., Salerno, F., Buraschi, E., Bruccoleri, G., and Smiraglia, C.: Lake surface area variations in the North-Eastern sector of Sagarmatha National Park (Nepal) at the end of the 20th Century by comparison of historical maps, J. Limnol., 67, 139-154, doi:10.4081/jlimnol.2008.139, 2008.

Tartari, G., Verza, P., and Bertolami, L.: Meteorological data at PYRAMID Observatory Laboratory (Khumbu Valley, Sagarmatha National Park, Nepal), in: Limnology of high altitude lakes in the Mt. Everest Region (Nepal), edited by: Lami, A. and Giussani, G., Mem. Ist. Ital. Idrobiol, 57, 23-40, 2002.

Tartari, G., Vuillermoz, E., Manfredi, E. C., and Toffolon, R.: CEOP High Elevations Initiative, GEWEX News, Special Issue, 19, 45, 2009.

Thakuri, S., Salerno, F., Smiraglia, C., Bolch, T., D’Agata, C., Viviano, G., and Tartari, G.: Tracing glacier changes since the 1960s on the south slope of Mt. Everest (central southern Himalaya) using optical satellite imagery, The Cryosphere, 8, 1297-1315, doi:10.5194/tc-8-1297-2014, 2014.

Themeß1, M. J., Gobiet, A., and Heinrich, G.: Empirical-statistical downscaling and error correction of regional climate models and its impact on the climate change signal, Clim. Change, 112, 449468, doi:10.1007/s10584-011-0224-4, 2012. 
Turner, A. G. and Annamalai, H.: Climate change and the South Asian summer monsoon, Nat. Clim. Change, 2, 587-595, doi:10.1038/nclimate1495, 2012.

Ueno, K. and Aryal, R.: Impact of tropical convective activity on monthly temperature variability during non monsoon season in the Nepal Himalayas, J. Geophys. Res., 113, D18112, doi:10.1029/2007JD009524, 2008.

Ueno, K., Endoh, N., Ohata, T., Yabuki, H., Koike, M., and Zhang, Y.: Characteristics of precipitation distribution in Tangula, Monsoon, 1993, B. Glaciol. Res., 12, 39-46, 1994.

UNEP (United Nations Environment Programme)/WCMC (World Conservation Monitoring Centre): Sagarmatha National Park, Nepal, in: Encyclopedia of Earth, edited by: McGinley, M. and Cleveland, C. J., Environmental Information Coalition, National Council for Science and the Environment, Washington, DC, 2008.

Vuille, M.: Climate variability and high altitude temperature and precipitation, in: Encyclopedia of snow, ice and glaciers, edited by: Singh, V. P., Singh, P., and Haritashya, U. K., Springer, 153156,2011

Wagnon, P., Vincent, C., Arnaud, Y., Berthier, E., Vuillermoz, E., Gruber, S., Ménégoz, M., Gilbert, A., Dumont, M., Shea, J. M., Stumm, D., and Pokhrel, B. P.: Seasonal and annual mass balances of Mera and Pokalde glaciers (Nepal Himalaya) since 2007, The Cryosphere, 7, 1769-1786, doi:10.5194/tc-7-17692013, 2013.

Washington, W. M. and Parkinson, C. L.: An introduction to threeDimensional Climate Modeling, 2nd Edn., University Science Books, Sausalito, 2005.
Wu, B.: Weakening of Indian summer monsoon in recent decades, Adv. Atmos. Sci. 22, 21-29, doi:10.1007/BF02930866, 2005.

Yang, J., Tan, C., and Zhang, T.: Spatial and temporal variations in air temperature and precipitation in the Chinese Himalayas during the 1971-2007, Int. J. Climatol., 33, 2622-2632, doi:10.1002/joc.3609, 2012.

Yang, X., Zhang, Y., Zhang, W., Yan, Y., Wang, Z., Ding, M., and Chu, D.: Climate change in Mt. Qomolangma region since 1971, J. Geogr. Sci., 16, 326-336, doi:10.1007/s11442-006-0308-7, 2006.

Yao, T., Thompson, L., Yang, W., Yu, W., Gao, Y., Guo, X., Yang, X., Duan, K., Zhao, H., Xu, B., Pu, J., Lu, A., Xiang, Y., Kattel, D. B., and Joswiak, D.: Different glacier status with atmospheric circulations in Tibetan Plateau and surroundings, Nat. Clim. Change, 2, 663-667, doi:10.1038/nclimate1580, 2012.

Yasutomi, N., Hamada, A., and Yatagai, A.: Development of a longterm daily gridded temperature dataset and its application to rain/snow discrimination of daily precipitation, Global Environ. Res., V15N2, 165-172, 2011.

You, Q., Kang, S., Pepin, N., Flügel, W., Yan, Y., Behrawan, H., and Huang, J.: Relationship between temperature trend magnitude, elevation and mean temperature in the Tibetan Plateau from homogenized surface stations and reanalysis data, Global Planet. Change, 71, 124-133, doi:10.1016/j.gloplacha.2010.01.020, 2010.

Zhao, H., Xu, B., Yao, T., Wu, G., Lin, S., Gao, J., and Wang, M.: Deuterium excess record in a southern Tibetan ice core and its potential climatic implications, Clim. Dynam., 38, 1791-1803, doi:10.1007/s00382-011-1161-7, 2012. 